\title{
BANK MARKET POWER AND SME FINANCING CONSTRAINTS
}

\author{
Santiago Carbó-Valverde \\ Department of Economics \\ University of Granada \\ Francisco Rodríguez-Fernández \\ Department of Economics \\ University of Granada \\ Gregory F. Udell \\ Kelley School of Business \\ Indiana University
}

This draft: December 2005

\begin{abstract}
Theoretical models of lending and industrial organization theory predict that firm access to credit depends critically on bank market structure. However, empirical studies offer mixed results. Some studies find that higher concentration is associated with higher credit availability consistent with the information hypothesis that less competitive banks have more incentive to invest in soft information. Other empirical studies, however, find support for the market power hypothesis that credit rationing is higher in less competitive bank markets. This study tests these two competing hypotheses by employing for the first time a competition indicator from the Industrial Organization literature - the Lerner index - as an alternative to traditional measures of concentration. We test the information and the market power hypotheses using alternative measures and firm borrowing constraints. We find that the results are sensitive to the choice between IO margins and traditional concentration measures. In particular, the HHI seems to support the information hypothesis while the Lerner index supports the market power hypothesis. The Lerner index, however, is found to be a more consistent indicator of market power across different measures of financing constraints. Moreover, the Lerner index is found to exhibit the larger marginal effect on the probability that a firm is financially constrained among a large set of firm level, bank market and environmental control variables. Our results are robust to alternative measures of financial constraints and cast doubt on the validity of relying on concentration measures as proxies of competition in corporate lending relationships (247 words).
\end{abstract}

Corresponding author: Gregory F. Udell, Finance Department, Kelley School of Business, Indiana University, 1309 East Tenth Street, Bloomington, IN 47405-1701, USA

e-mail address: gudell@indiana.edu

ACKNOWLEDGEMENTS: The authors thank the Spanish Savings Banks Foundation (Funcas) for financial support. We thank comments from Allen Berger, Tim Hannan and Joaquin Maudos. We also thank comments from Tony Saunders, José Manuel Campa, Hans Degryse and other participants in the I Fall Workshop on Economics held in Granada in October 2005. 


\section{Introduction}

The potential impact of financial institution structure on access to external finance and economic growth has garnered considerable interest recently among researchers as well as policymakers (e.g., Demirguc-Kunt and Maksimovic, 1998, 1999; Rajan and Zingales, 1998; Boot and Thakor, 2000; Berger et al., 2004, Berger and Udell, forthcoming). A particularly interesting dimension of financial institution structure is the competitiveness of the banking industry. The traditional market power view has been that concentrated banking markets are associated with less credit availability and a higher price for credit. However, an alternative view has emerged over the past decade that argues that the impact of competition on credit may be related to the level of asymmetric information in the market (Dell'Ariccia and Marquez, 2005). In particular, this information hypothesis argues that competitive banking markets can weaken relationshipbuilding by depriving banks of the incentive to invest in soft information. Therefore, less competitive markets may be associated with more credit availability (Petersen and Rajan, 1995).

The issue of bank competition and credit availability may matter most for small and mid-sized enterprises (SMEs) for two reasons. First, SMEs are more vulnerable to information problems. Second, SMEs are much more bank-dependent than large enterprises. The debate over the link between bank competition and SME access to credit has become an urgent policy issue because the structure of the global banking system has been significantly affected by consolidation. The extent to which policymakers should be concerned about the impact of consolidation on banking market competitiveness may 
crucially depend on whether competition has a positive or negative impact on SME access to credit.

Despite the policy relevance of this issue, empirical interest in this topic is relatively recent and the existing papers find different and conflicting results. On the one hand, some papers have found evidence consistent with the market power hypothesis that competition enhances access to credit (e.g., Jayaratne and Wolken, 1999; Boot and Thakor, 2000; Ongena and Smith, 2001, and Scott and Dunkelberg 2005, Elsas 2005). On the other hand, other papers have found evidence consistent with the information hypothesis (e.g., Petersen and Rajan, 1995, Zarutskie, 2003, Berger et al. forthcoming). The methodologies and the data sets reflected in this literature vary considerably.

We add to this empirical literature on the association between market power and SME access to credit in several important ways. First, unlike the extant literature on competition and credit availability, our examination does not rely on concentration as our primary measure of market power. Several contributions to the banking literature during the last two decades have cast doubt on the consistency and robustness of concentration as an indicator of market power (Berger, 1995; Rhoades, 1995; Jackson 1997; Hannan, 1997; Dick, 2005). Applications to the banking industry such as Shaffer (1993), Ribon and Yosha (1999) or Maudos and Fernández de Guevara (2004) have already shown that price to marginal costs indicators, such as the Lerner index, are much more robust measures of the exercise of bank market power and are frequently uncorrelated with concentration indicators. This suggests the possibility that the mixed empirical results in the credit availability/market power debate may in part be due to the imprecise nature of concentration as a measure of market power. We avoid this problem by emphasizing our 
tests that use the Lerner index as our proxy for market power. We also highlight the severity of this problem in the context of the competition/credit availability issue by examining whether the Lerner index and traditional measures of concentration give consistent results.

Second, our data set is quite large and contains extensive information about both borrowing firms and the banks from which they obtain financing. The richness of our data allows us to analyze the robustness of our findings on the association between credit availability and market power. In particular we analyze the robustness of our results against a variety of different measures of firm-level credit constraints found in the literature. In our analysis we are able to deploy a dynamic panel approach that accounts for potential endogeneity in the data, using standard measures of credit constraints and, as an alternative, a disequilibrium methodology found in some recent papers that estimates excess demand for external funds (Ogawa and Suzuki, 2000, Atanasova and Wilson, 2004 and Shikimi, 2005).

Third, our data is from Spain which may offer a particularly advantageous environment in which to analyze this issue. Spain has a banking-oriented financial system with a large fraction of its economic activity driven by the SMEs sector. In 2004, there were 2,9 million SMEs in Spain, representing the $99.87 \%$ of total firms and the $51 \%$ of total employment. Spain also has considerable variation in local bank market power. As in many other European countries ${ }^{1}$, provincial and regional bank markets have been found to exhibit significant differences in terms of concentration, prices and other

\footnotetext{
${ }^{1}$ See, for example, Angelini and Cetorelli (1999) for Italy.
} 
competition indicators (Carbó et al., 2003) which makes it an ideal laboratory to investigate this issue ${ }^{2}$.

By way of preview, our most important finding is that our regression results depend crucially on how market power is measured. In particular, our results generally indicate a negative association between market power and credit availability when the Lerner Index is used to measure market power. However, when concentration is used our findings, in general, are reversed. Given the documented deficiencies associated with the concentration we argue that our results do not provide on balance support for the information hypothesis. Also, our results caste some doubt on the findings in the literature on competition and relationship lending which has been dependent on concentration as a measure of market power. The universal use of concentration in this literature may also explain the conflicting results it has produced.

We proceed in our paper in the next section with a review of two literatures: the literature on relationship lending and concentration, and the literature on measures of market power. The data employed is described in section 3. In Section 4 we introduce a dynamic panel methodology to analyse firm financing constraints using accounting ratios as proxies of borrowing constraints. Section 5 introduces an alternative classification of constrained and unconstrained firms from a disequilibrium model of firm financing behavior. This classification is then employed as a binary choice in a probit model in

\footnotetext{
${ }^{2}$ Spain may also be a relatively more attractive environment for studying relationship lending because Spanish banks may focus more on relationship lending than some other countries, particularly the U.S. In the U.S. lenders have historically had more transactions-based lending technologies that can be used in lending to opaque SMEs such as small business credit scoring than in Spain. Because these lending technologies are not relationship-based, their deployment by lenders would not be dependent on market power even if the information hypothesis is operable. This creates a problem for empiricists who wish to test the information hypothesis which applies only to relationship lending and not to transactions-based lending because the lending technologies are not directly observable in any of data sets currently used in the literature (Berger and Udell, forthcoming). Thus, tests of the information hypothesis will be more powerful in countries such as Spain where relationship lending is likely the dominant lending technology.
} 
section 6 to estimate the probability that a firm is financially constrained. We further discuss additional robustness check in Section 7. Section 8 offer conclusions.

\section{Related Literature}

\section{II.A. The Literature on Relationship Lending and Competition}

The seminal work of Stiglitz and Weiss (1981) suggested that deviations from the perfect markets assumption of symmetric information could explain the existence of a loan market equilibrium characterized by excess demand for credit. This, in turn, spawned a keen interest among economists in explaining how financial system architecture might mitigate this problem. Initially much of this research effort was focused on the role of financial institutions resulting in the development of the modern theory of banks as delegated monitors (e.g., Diamond, 1984, Ramakrishnan and Thakor, 1984; Boyd and Prescott, 1986). Subsequent empirical work found support for this "uniqueness" view of banks (e.g., James, 1987; Lummer and McConnell, 1989). Arguably, the problems created by asymmetric information are more acute for SMEs than large enterprises because these firms are much more informationally opaque (e.g., Berger and Udell, 1998). Thus, the role of banks may be most important in providing credit to SMEs.

Later in the decade attention began to shift to an examination of exactly how banks mitigated the problems that arise from asymmetric information about borrower quality. Research initially focused on specific contract terms that banks use in constructing commercial loan contracts - a strand of the literature that continues today. These contract terms include outside collateral (Bester, 1985; Stiglitz and Weiss, 1986; 
Chan and Kanatas, 1985; Besanko and Thakor, 1987a,b; Boot, Thakor, and Udell, 1991; Berger and Udell, 1990), inside collateral (e.g., Smith and Warner, 1979; Stulz and Johnson, 1985; Swary and Udell, 1988; Gorton and Kahn, 1997; Welch, 1997; Klapper, 1998; John, Lynch, and Puri, 2003), personal guarantees (e.g., Avery et al., 1998; Berger and Udell, 1998; Lel and Udell, 2002), and forward commitments (Melnik and Plaut, 1986; Boot, Thakor, and Udell, 1987; Kanatas, 1987; Thakor and Udell, 1987; Sofianos, Wachtel and Melnik, 1990; Berkovitch and Greenbaum, 1991; Avery and Berger, 1991a; Berger and Udell, 1992; Morgan 1994, 1998). ${ }^{3}$

In the 1990s researchers began to examine a potentially more comprehensive explanation for how banks and other financial institutions might mitigate information problems in SME commercial lending. This approach has focused on "lending technologies" rather than on individual elements of the commercial loan contract. A lending technology can be defined as a combination of screening mechanisms, contract elements, and monitoring strategies (Berger and Udell, forthcoming). Most of the attention in this strand of the literature has focused on one specific lending technology, "relationship lending" first formally modeled in Petersen and Rajan (1995). Relationship lending "is based significantly on 'soft' qualitative information gathered through contact over time with the SME and often with its owner and members of the local community" (Berger and Udell, forthcoming). Soft information can include assessments of an SME's future prospects compiled from past interactions with its suppliers, customers, competitors, or neighboring businesses (Petersen and Rajan, 1994; Berger and Udell, 1995; Mester et al., 1998; Degryse and van Cayseele, 2000). The balance of the

\footnotetext{
${ }^{3}$ Outside collateral refers to collateral that is not the property of the borrowing firm. Typically this involves assets owned personally by the entrepreneur such as real estate. Inside collateral refers to collateral that is the property of the borrowing firm (see Berger and Udell, 1998).
} 
empirical evidence suggests that the strength of the bank-borrower relationship is positively related to credit availability and credit terms such as loan interest rates and collateral requirements (e.g., Petersen and Rajan, 1994, 1995; Berger and Udell, 1995; Cole, 1998; Elsas and Krahnen, 1998; Harhoff and Körting 1998a). ${ }^{4}$ This research has also investigated the propensity of different types of banks to provide relationship lending with the general conclusion being that smaller domestic banks may have comparative advantage in delivering relationship lending (e.g., Hannan, 1991; Haynes, Ou, and Berney 1999; Stein, 2002; Berger and Udell, 2002; Haynes, Ou, and Berney, 1999; Berger and Udell, 1996; Berger, 2004; Carter et al., 2004; Cole, Goldberg and White, 2004; Carter and McNulty, 2005; Berger et al., 2005).

A key unresolved issue associated with relationship lending is the link between market power and the feasibility of this lending technology. In particular, a key feature of the Petersen and Rajan (1995) (PR) theoretical model of relationship lending is the role of competition. ${ }^{5}$ PR demonstrate theoretically that when loan markets are competitive commercial lenders will have less incentive to invest in relationship building. This is the essence of the information hypothesis introduced in the first section of our paper. Interestingly, an alternative theoretical model suggests that competitive markets may be

\footnotetext{
${ }^{4}$ There is now very large literature on relationship lending much of which addresses the specific issue of the association between the strength of the bank-borrower relationship and credit availability and price. No less than three survey articles have been published that are substantially or entirely devoted to the subject of relationship lending (Berger and Udell, 1998; Boot; 2000; and Elyasiani and Goldberg, 2004). Collectively these surveys contain a comprehensive assessment of the evidence linking relationship strength and credit availability - both pro and con.

${ }^{5}$ Another theoretical model suggests that the impact of competition involves a trade-off between the borrower's incentive problem and higher monitoring effort but when the second effect dominates it is optimal for banks to have some market power (Caminal and Matutes, 2002). There is also a paper that offers a model that includes both informational effects associated with the incentive to acquire private information along with the traditional (i.e., SCP) effects that work to restrict the supply of credit. This model shows that net effect depends on the cost of information access and is ultimately an empirical issue (de Mello 2004).
} 
conducive to relationship building (Boot and Thakor, 2000). ${ }^{6}$ More broadly the information hypothesis is inconsistent with the traditional 'market power' view of market that argues that competition promotes credit availability - our market power hypothesis. The resolution of these conflicting views is not only interesting from the perspective of understanding the nature of relationship lending, it also interesting because the issue of the competitiveness of the global banking industry has become a front-burner issue given the possibility that the global consolidation of the banking industry could produce a less competitive commercial loan market. Of particular concern is the prospect that consolidation could lead to a contraction in the number of banks that specialize in relationship lending - smaller community banks. ${ }^{7,8}$

Which of these views best describes the nature of relationship lending - the information hypothesis vs. the market power hypothesis - is ultimately an empirical issue. As we noted in the introduction, however, the relatively new empirical literature on this controversy is split. This literature has collectively deployed a number of different methodologies and national data sets. The bulk of the papers in this literature directly test these hypotheses in the sense that market power is a key explanatory variable. Unlike our analysis, all of these papers solely rely on concentration variables to measure market power in local banking markets.

Some of the papers that have empirically investigated the information vs. market power hypotheses use measures of dependence on trade credit as proxies for credit

\footnotetext{
${ }^{6}$ There is also theoretical work that suggests that increased competition in loan markets is associated with more credit availability for "informationally captured" firms and is associated with a decrease in quality of informed banks' loan portfolios (i.e., a 'flight to captivity) (Dell'Ariccia and Marquez, 2005).

${ }^{7}$ For an analysis of the current and potential future role of small community banks in providing relationship lending in a U.S. context, see DeYoung et al., 2004).

${ }^{8}$ For a comprehensive summary of the broader literature on bank competition and concentration as it relates to the performance of banks see Berger et al. (2004).
} 
availability. The implicit assumption in these papers is that trade credit is one of the most expensive forms of external finance. These papers, for example, find support for the information hypotheses by showing a positive correlation between the level competition and dependence on trade credit (Petersen and Rajan, 1995; de Mello, 2004; and Fisher, 2005). ${ }^{9}$ Other methodologies using standard measures of concentration have also provided, on balance, support for the information hypothesis including: a study that used U.S. Internal Revenue Service data to examine the probability of receiving a loan and disbursement loans (Zarutskie, 2003); a cross-country analysis that found that concentration is associated with growth in industrial sectors that are more dependent on external finance (Cetorelli and Gambera, 2001); and, a study that found that banks in more concentrated markets acquire more information about their borrowers (Fisher, 2005).

Several other analyses have either found a lack of evidence to support the information hypothesis or found support for the market power hypothesis. Returning to the dependence on trade credit, two studies did not find any association between concentration and dependence on trade credit (Jayaratne and Wolken, 1999, and Berger et al., 2004). One study found that Hausbank status is positively related to better access to information and that the likelihood of observing a Hausbank relationship is positively related to competition in the market, at least for low and intermediate levels of concentration (Elsas, 2005). Another study using survey data found that entrepreneurs' perception of the quality of service and credit availability was positively related to competition (although loan rates were not) (Scott and Dunkelberg, 2005).

\footnotetext{
${ }^{9}$ One recent paper points out that the evidence that trade is expensive is weak. Moreover, this paper argues that it is difficult to reconcile the ubiquitous nature of trade credit with it being a relatively expensive source of credit (Miwa and Ramseyer 2005).
} 
Some studies have found indirect evidence inconsistent with the information hypothesis. Two studies have found evidence inconsistent with the "lock-in" element of the PR (1995) model (and other theoretical models, e.g., Sharpe, 1990; and Petersen and Rajan, 1992). One indirect analysis, however, can be viewed as providing support for the information hypothesis finding in one of two empirical specifications a positive association between the strength of a banking relationship as measured by its length and the level of concentration in the market (Berger et al., 2004).

One final note on the literature related to our study. Until very recently the research literature on lending technologies has focused implicitly on just two categories relationship lending and transactions lending. The implicit assumption in this literature has been that "transactions lending" is a single homogeneous lending technology that differs from relationship lending in that it is based on hard information rather than soft information. Furthermore, relationship lending is ideally suited for providing credit to informationally opaque SMEs while transactions lending is ideally suited for informationally transparent enterprises - large enterprises and possible some larger SMEs. This dichotomous view dovetails nicely with the research findings noted above that indicate that small banks have a comparative advantage in relationship lending while large banks have a comparative in transactions lending.

Recent work, however, notes that this paradigm is incomplete and misleading on one key dimension: the assumption that transactions lending is a single homogeneous lending technology. Specifically, this research highlights that there are many transactions lending technologies including financial statement lending (which relies on audited 
financial statements), asset-based lending ${ }^{10}$, factoring, small business credit scoring, fixed asset lending and leasing. This new research points out that the last five of these are ideally suited for some types of opaque SMEs. This research also points out that data limitations have made it virtually impossible to control for these technologies in credit availability research even though all but one of these technologies has been in existence for decades - in at least some countries (Berger and Udell, forthcoming). Small business credit scoring, the exception, has been existence in at least one country, the U.S., for over a dozen years.

The inability to control for the lending technology is particularly problematic for studies that test the information hypothesis because this hypothesis only applies to one lending technology, relationship lending. Arguably this problem is most acute for studies that test the information hypothesis using U.S. data because all of these technologies exist in significant amounts in the U.S. (Berger and Udell, forthcoming). Many of the empirical studies identified above were indeed based on U.S. data and, therefore, are most vulnerable to this criticism. ${ }^{11}$ As we noted in the introduction, one virtue of using Spanish data is that it is highly likely that most of the borrowers in our data set our relationship borrowers. Certainly, in comparison to the U.S., this is likely to be the case because neither asset-based lending nor small business credit scoring exist in Spain.

\footnotetext{
${ }^{10}$ The term "asset-based lending" has been used in many different contexts. Here we are using the term to refer strictly to the well-defined category of lending that deploys intensive and idiosyncratic monitoring techniques in conjunction with lending against accounts receivable, inventory and equipment (Udell, 2004). In the four countries in the world where this type of lending exists (Australia, Canada, the U.K. and the U.S.), there are separate industry associations connected to this technology (e.g., the Commercial Finance Association in the U.S.).

${ }^{11}$ The studies cited above that depend on U.S. data are Petersen and Rajan (1995), Jayaratne and Wolken (1999), de Mello (2004), Zarutskie (2003), Berger et al. (2004), Scott and Dunkelberg (2005).
} 


\section{II.B. The Literature on Proxies of Market Power}

A key distinction between our paper and the existing literature on market power and credit availability is that we do not rely on measures of local banking market concentration as our measure of market power. Many empirical studies have considered concentration as a proxy for bank market power following the Structure-ConductPerformance (SCP) paradigm (Berger and Hannan, 1989; Hannan and Berger, 1991). However, several contributions to the banking literature during the last two decades have cast doubt on the consistency and robustness of concentration as an indicator of market power (Berger, 1995; Rhoades, 1995; Jackson 1997; Hannan, 1997). Although the SCP hypothesis of a positive relationship between concentration and profits can be derived from oligopoly theory under the assumption of Cournot behavior, it is not warranted under alternative models. Some empirical studies have even tested and rejected the hypothesis of Cournot conduct in the banking industry (Roberts, 1984; Berg and Kim, 1994). Econometric developments have permitted the emergence of empirical papers from the so-called New Empirical Industrial Organization (NEIO) perspective, by directly estimating the parameters of a firm's behavioral equation to directly obtain price to marginal costs indicators such as the Lerner Index (Schmalensee, 1989). Although price to marginal costs indicators are not "new" from a theoretical standpoint, marginal costs have only been econometrically estimated during the last two decades. Applications to the banking industry as Shaffer (1993), Ribon and Yosha (1999) or Maudos and Fernández de Guevara (2004) have already shown that these price to marginal costs indicators are frequently uncorrelated with concentration ratios. This issue of the choice 
of the appropriate proxy for market power is crucial if bank market structure conditions significantly determine the ability of firms to obtain funding.

\section{Data}

The dataset contains firm-level information from the Bureau-Van-Dijk Amadeus database. Our sample consists of 30,897 Spanish SMEs using annual data for the period 1994-2002. It is a balanced panel and it sums up to 278,073 panel data observations. $75.71 \%$ of the firms are small firms $(23,394)$, while the $24.29 \%(7,503)$ are medium-sized firms. We define the 17 administrative regions of Spain as the relevant markets for firms. The sample composition across regions and sectors is shown in Table 1. Consistent with our market definition, the set of variables that describe the banking conditions have been computed as weighted averages of the values of these variables for the banks operating in these regions (using bank total assets as the weighting factor). These bank market variables have been computed from an auxiliary sample of individual bank balance sheet and income statement data that represent more than the $90 \%$ of total bank assets in Spain $^{12}$.

There are four different sets of variables: (i) firm financing constraints that comprise our dependent variables; (ii) firm characteristics that affect firm financing decisions; (iii) bank market characteristics, including concentration and price to marginal cost competition indicators; and (iv) environmental financial and economic control variables.

\footnotetext{
${ }^{12}$ The bank sample consists of 38 commercial banks and the 46 savings banks operating in Spain. Balance sheet and income statement information were provided by the Spanish Commercial Banks Association (AEB) and the Spanish Savings Bank Confederation (CECA).
} 


\section{III.A Dependent Variables}

With regard to our dependent variables, firm financing constraints, we use, various trade credit and lending ratios:

- Trade credit/total liabilities: Our first alternative measure of financing constraints is dependence on trade credit. It is probably the most widely employed proxy for firm financing constraints. Its use is justified by the assumption that trade credit is effectively the most expensive source of SME financing because of the common practice of offering high discounts for early payment (e.g., Petersen and Rajan 1995, de Mello 2004 and Fisher 2005).

- Trade credit/tangible assets: As an alternative to normalizing the amount of trade credit by total liabilities, we use trade credit normalized by tangible assets. Tangible assets may sustain more external financing because tangibility mitigates contractibility problems (Almeida and Campello, 2004). If tangible assets act in this fashion, and trade credit is the most expensive source of external credit then we would expect that unconstrained firms would use trade credit relative to tangible assets.

- Sales growth: This variable is likely both directly and indirectly related to firm financing constraints. On the one hand, it has been employed as a measure of investment opportunities and current cash-flows, which are expected to reduce borrowing constraints (Fazzari et al. 2000). On the other hand, Lamont et al. (2001) also employed the negative values of sales growth as an indicator of financial distress for constrained firms.

Some research indicates that the assumption that trade credit is the most (or one of the most) expensive source of SME finance is based on an overly-simplistic calculation of its cost. These estimates of the annual rate on trade credit is computed from only two 
of the terms of credit: the discount (e.g., $2 \%$ in ten days) the stated maturity (e.g., net 30 days). This calculation, it is argued, ignores at least two other pricing elements: the price of the underlying goods and the actual maturity (which may be very different from the stated maturity). Moreover, the ubiquitous nature of trade credit globally appears inconsistent with it being the most expensive source of external finance (Miwa and Ramseyer 2005). Similarly, Kaplan and Zingales (1997) demonstrates that the relationship between investment-cash flow correlations and borrowing constraints are likely to vary significantly depending on the level of sales. As an alternative measure of credit constraints we use:

- Loans/tangible assets: As we noted above tangible assets can mitigate information problems associated with financial contracting. These assets can be used, for example, for collateral in bank loans. Thus, the loans/tangible assets ratio can be viewed as a loan-to-value ratio that reflects a lender's willingness to lend against hard assets. This ratio can also be viewed as a robustness check for our variable "trade credit/tangible assets". The trade credit/tangible assets and loans/tangible assets should offer the opposite results holding constant potential accounting bias in both cases.

\section{III.B.1. Explanatory Variables - Market Power}

Our key explanatory variables, and the main focus or our paper, are our two alternative measures of market power:

- HHI bank deposits: This variable is the Herfindahl-Hirschman concentration index in the deposit markets. This index is computed as the sum of the squared market shares of each one of the banks operating in a given region. Existing studies offer 
controversial results as far as the relationship between concentration and funding availability is concerned. Some studies have found evidence that concentration has positive effects on credit availability (i.e., Cetorelli and Gambera 2001, and Fisher 2005). However, other studies have found evidence of the negative effects of concentration of firm financing (i.e., Jayaratne and Wolken 1999, and Berger et al., 2004). The coefficient on HHI bank deposits will enable us to compare the impact of concentration on financing constraints in Spain with the results found in other countries.

- Lerner index: The Lerner index is defined as the ratio "(price of total assetsmarginal costs of total assets)/price". The price of total assets is directly computed from the bank-level auxiliary data as the average ratio of "bank revenue/total assets" for the banks operating in a give region. Marginal costs are estimated from a translog cost function with a single output (total assets) and three inputs (deposits, labor and physical capital). A detailed specification of the translog function employed is given in Appendix A. To our knowledge, there are no previous papers employing the Lerner index as a measure of competition to study firm financing constraints.

\section{III.B.2. Explanatory Variables - Other Bank Market Characteristics}

- Average bank size: This variable is measured as the log of the ratio "total assets of banks operating in a given region/number of bank institutions in this region”. Some previous studies on the relationship between bank size and SMEs financing argue that there are potential disadvantages for large banks in lending to informationally opaque small businesses. Large banks are hypothesized to have difficulty extending relationship loans to informationally opaque small businesses because of organizational diseconomies 
of providing relationship lending services (Williamson 1967, 1988) and because "soft" information may be difficult to transmit through the communication channels of large organizations (Stein 2002) and may create agency problems (Berger and Udell 2002). However, Berger et al. (forthcoming) did not find evidence that larger banks make disproportionately fewer small business loans. They argue that large banks tend to adjust to the competitive conditions in local markets. They also may have this capacity due to the existence of internal capital markets. As they are large enough and they operate in various regional markets, large banks may transfer liquidity from one region to another region (Houston and James, 1998).

- Bank credit risk: Bank credit risk is measured by the average ratio of "loan losses to total loans" in a given region. We use this variable to control for any differences across regions in the propensity of banks to supply credit to borrowers of different risk. It may also capture any differences across regions in the supply of bank credit related to the ex post performance of their loan portfolios.

- Number of bank branches: This a bank service variable reflecting the physical bank infrastructure available in the region where this firm operates. Lending restrictions are expected to be lower in those regions where bank services are more widespread. Studies such as Jayaratne and Wolken (1999) have shown that branching deregulation, and the subsequent increase of bank branches in regional markets in the US resulted in lower financing constraints for SMEs.

- Bank profitability: the standard return on assets (ROA) ratio is employed as a measure of bank profitability. Bank profitability is typically used as a control variable to 
capture any link between bank performance and the local supply of credit (Carter et al., 2004).

- Bank inefficiency: the average ratio "operating expenses/gross income" in a given region is employed as a bank cost efficiency measure. More inefficient bank markets are expected to reflect an inferior allocation of resources which may be associated with firms in the market facing higher financing constraints (Schiantarelli, 1995; Hubbard, 1998).

\section{III.B.3. Explanatory Variables - Firm Characteristics}

- Firm inefficiency: This is the ratio of firm operating costs to income. This ratio is included to control for the potential the effects of differences in firm cost management on financing decisions. In particular, firms that exhibit higher operating inefficiency may rely more frequently on trade credit and other expensive sources of funding (Petersen and Rajan, 1995). Similarly, operating inefficiency may affect performance negatively and become a bad signal for bank credit scoring and, hence, loan supply (Bechetti and Sierra, 2003).

- Firm profitability: Profitability is measured as the ratio of profit before taxes over total assets is employed as a measure of economic performance. The literature on credit constraints (Evans and Jovanovic, 1989; Greenwald and Stiglitz, 1993; Schiantarelli, 1995; Hubbard, 1998) suggests that they can cause a misallocation of resources in firm production. This misallocation of inputs can then cause the creditconstrained firm to have lower profit levels than its unconstrained competitor. 
- Firm size: Firm size is defined as the log of total assets. Cross-country studies of financing choices have found different financing patterns for small and large firms, in the use of long-term financing and trade credit (Demirguc-Kunt and Maksimovic, 1999 and 2001). Large firms may benefit from internal capital markets and face less financing constraints while small firms use trade credit more intensively.

\section{III.B.4. Explanatory Variables - Environmental and Regional Controls}

Our environmental control variables are also computed on a regional basis in order to control for other regional factors that may affect credit availability:

- GDP: GDP is the real regional gross domestic product. This variable accounts for differences in the economic development across the regions where SMEs are located.

- Taxation: This is the ratio "taxes/earnings before interest and taxes" reflect differences in firm earnings taxation across regions that may result in "artificial" asymmetries in firm profitability.

- Percentage urban population: This is the ratio "population in areas with more than 10,000 inhabitants in the region/total population in the region", which captures any differences in urban versus rural markets.

- Number of bankrupticies: this variable measures the evolution of firm bankruptcies across regions, as a proxy of firm financial stability across regions.

The mean values of all variables across time and for the entire period are shown in Table 2. 


\section{The relationship between market structure and firm financing constraints: a dynamic panel approach}

\section{A. Dynamic panel methodology}

As a first approach to assessing the relationship between SME financing constraints and bank market power, we us a set of dynamic panel estimations, employing our four borrowing constraint ratios as alternative dependent variables: "trade credit/total liabilities", "sales growth", "trade credit/tangible assets" and "loans/tangible assets". The dynamic panel methodology relies on the Generalized-Method of Moments (GMM) estimator suggested by Arellano and Bond (1991). This dynamic panel data procedure is employed since the lagged values of the financing constraints variables are likely to determine, at least partially, the current levels of borrowing constraints. Consider the following regression equation,

$y_{i, t}-y_{i, t-1}=(\alpha-1) y_{i, t-1}+\beta^{\prime} X_{i, t}+\eta_{i}+\varepsilon_{i, t}$

where $\mathrm{y}$ is the financing constrain variable, $X$ is a set of explanatory variables representing firm characteristics, bank market conditions and environmental control factors, $\eta_{i}$ is an unobserved firm-specific effect, $\varepsilon$ is the error term. The subscripts $i$ and $t$ represent the firm and time period, respectively. Equation (1) can be rewritten as:

$$
y_{i, t}=\alpha y_{i, t-1}+\beta^{\prime} X_{i, t}+\eta_{i}+\varepsilon_{i, t}
$$

The firm-specific effect is eliminated by taking first-differences in equation (2) so that:

$$
y_{i, t}-y_{i, t-1}=\alpha\left(y_{i, t-1}-y_{i, t-2}\right)+\beta^{\prime}\left(X_{i, t}-X_{i, t-1}\right)+\left(\varepsilon_{i, t}-\varepsilon_{i, t-1}\right)
$$

All variables are expressed in logs so that the differences can be interpreted as growth rates. The use of appropriate instruments is necessary to deal with the likely 
endogeneity of the explanatory variables, and also to deal with the fact that the new error term $\left(\varepsilon_{i, t}-\varepsilon_{i, t-1}\right)$ is correlated with the lagged dependent variable $\left(y_{i, t-1}-y_{i, t-2}\right)$. Under the assumptions that the error term $(\varepsilon)$ is not serially correlated, and that the explanatory variables, $X$, are weakly exogenous (the explanatory variables are assumed to be uncorrelated with future realization of the error term) the GMM dynamic panel estimator uses the following moment conditions.

$$
\begin{aligned}
& E\left[y_{i, t-s} \cdot\left(\varepsilon_{i, t}-\varepsilon_{i, t-1}\right)\right]=0 \text { for } s \geq 2 ; t=3, \ldots . . T \\
& E\left[X_{i, t-s} \cdot\left(\varepsilon_{i, t}-\varepsilon_{i, t-1}\right)\right]=0 \text { for } s \geq 2 ; t=3, \ldots . . T
\end{aligned}
$$

We refer to the GMM estimator based on these conditions as the 'difference estimator'. However, there are some statistical shortcomings with this difference estimator. Blundell et al. (2000) have shown that when the explanatory variables are persistent over time, lagged levels of these variables are weak instruments for the regression equation in differences and affect the asymptotic and small-sample performance of the difference estimator. Asymptotically, the variance of the coefficients rises with weak instruments. Additionally, in small samples, Monte Carlo experiments have shown that the weakness of the instruments can produce biased coefficients. To reduce the potential biases and inaccuracy associated with the usual difference estimator, we use a new estimator that combines, in a system, the regression in differences with the regression in levels (Arellano and Bover, 1995; Blundell et al. 2000) ${ }^{13}$. The instruments for the regression in differences are the same as above. The instruments for the regression in levels are the

\footnotetext{
${ }^{13}$ In dynamic panel data models where the observations are highly autoregressive and the number of time series is small, the standard GMM estimator has been found to have large finite simple bias and poor precision in simulation studies. The poor performance of the Standard GMM panel data estimator is also frequent in relatively short panels with highly persistent data. The GMM system estimator improves the performance of the GMM estimator in the dynamic panel data context. Additionally, the GMM system estimator produces substantial asymptotic efficiency gains relative to this nonlinear GMM estimator, and these are reflected in their finite sample properties (Blundell et al., 2000).
} 
lagged differences of the corresponding variables. These are appropriate instruments under the following additional assumption: although there may be correlation between the levels of the right-hand side variables and the firm-specific effect in equation (2), there is no correlation between the differences of these variables and the firm-specific effect. This assumption results from the following stationarity properties:

$$
E\left\lfloor y_{i, t+p} \cdot \eta_{i}\right\rfloor=E\left\lfloor y_{i, t+q} \cdot \eta_{i}\right\rfloor
$$

and

$$
E\left[X_{i, t+p} \cdot \eta_{i}\right\rfloor=E\left[X_{i, t+q} \cdot \eta_{i}\right\rfloor \text { for all } p \text { and } q
$$

The additional moment conditions $p$ for the second part of the system (the regression in levels) are:

$$
E\left[\left(y_{i, t-s}-y_{i, t-s-1} \cdot\left(\eta_{i}+\varepsilon_{i, t}\right)\right]=0 \text { for } s=1\right.
$$

and

$$
E\left[\left(X_{i, t-s}-X_{i, t-s-1} \cdot\left(\eta_{i}+\varepsilon_{i, t}\right)\right]=0 \text { for } s=1\right.
$$

Thus, we use the moment conditions shown in equations (4), (5), (7) and (8) and employ a GMM procedure to generate consistent and efficient parameter estimates. Consistency of the GMM estimator depends on the validity of the instruments. The Sargan test of over-identifying restrictions is then employed to test the overall validity of the instruments by analyzing the sample analog of the moment conditions used in the estimation process.

\section{B. Dynamic panel results}

Table 3 shows the results of the dynamic panel data estimation where "trade credit/total liabilities" and "sales growth" are the dependent variables. There are two 
specifications for each dependent variable alternatively including the HHI of bank deposits and the Lerner index. The values of the F-test indicate the high overall statistical significance of these equations while the outcomes of the Sargan test suggest that the instruments employed are appropriate. The statistical significance of the lagged dependent variables highlights the importance of accounting for endogeneity when analysing firm financing constraints. The main focus of our analysis are our two alternative measures of competition. The results in Table 3 show that the concentration measure (HHI) and the other "market power" indicator (Lerner Index) offer the opposite results. In particular, bank concentration is negatively and significantly related to "trade credit/total liabilities" and positively to sales growth. However, the Lerner index suggests that higher bank market power is associated with a more intensive use of trade credit and a lower sales growth. Our results suggest that, at a minimum, studies of financing constraints that rely exclusively on concentration as a measure of market power may not be robust to alternative specifications. Moreover, the literature on market power in banking suggests that the Lerner index is the more accurate measure of realized bank competition than the HHI for two reasons: (i) the Lerner index relies directly on banklevel observation of pricing behaviour relative to estimated marginal costs; (ii) the HHI has been shown to offer spurious results and to be frequently uncorrelated to the Lerner index (Shaffer, 1993; Ribon and Yosha, 1999; Maudos and Fernández de Guevara, 2004). Under this interpretation that the Lerner index is the superior measure, the first set of results supports the market power hypothesis but not the information hypothesis.

Other bank market characteristics are also found to affect firm borrowing constraints significantly. Average bank size is found to be negatively and significantly 
related to firm borrowing constraints. This evidence is consistent with Berger et al. (forthcoming) and the view that large banks are not necessarily disadvantaged in providing loans to small business since they can benefit from internal capital markets and they have the ability to adapt to local market competitive conditions. Credit risk is negatively and significantly related to the use of trade credit which, in turn, may reflect that higher borrower risk (possibly driven by moral hazard and adverse selection problems) are associated with increased financial constraints. As expected, higher bank profitability and service (number of bank branches) are negatively and significantly related to "trade credit/total liabilities" and positively to sales growth.

Among the firm characteristic variables, size is the most significant variable and it shows that larger SMEs seem to rely more on trade credit than the smaller firms and exhibit a lower sales growth. The second specification for "trade credit/total liabilities" also suggests that higher firm inefficiency and lower profitability result in higher financing constraints.

The environmental control variables reveal that borrowing constraints are lower in those regions where firms benefit from higher GDP growth and a more favourable taxation scheme. However, the percentage of urban population is positively related to firm financing constraints, indicating that a firm opacity may be correlated with urban environment. Additionally, a higher number of bankruptcies in the region where the firm operates is also positively related to firm borrowing constraints, since financial instability may reflect a lower quality of investment opportunities for banks.

Table 4 shows the results of the dynamic panel estimations when "trade credit/tangible assets" and "loans/tangible assets" are included as additional financing 
constraint ratios for robustness. The results are quite in line with those of Table 3, showing that our results are robust to alternative specifications of borrower financial constraints. That is, the results in Table 4 confirm that higher market power measured by the Lerner index is negatively related to credit availability and higher market power measured by HHI of bank deposits is negatively related to credit availability.

\section{A disequilibrium model of firm financing constraints}

\section{V.A. The disequilibrium model: empirical approach}

Although accounting ratios can be consistent proxies of firm financing constraints, it is also possible to observe lending demand and availability and to estimate the probability of credit rationing from a disequilibrium model. We set up a model of bank loan demand by individual firms, allowing for the possibility that the firms cannot borrow as much as they would like. A disequilibrium model with unknown sample separation, as described by Maddala (1983), is employed. The basic structure of the model consists of two reduced-form equations: a desired demand equation for bank loans and a availability equation that reflects the maximum amount of loans that banks are willing to lend on a collateral basis; and a third equation: a transaction equation. In this model, the realized loan outstanding is determined by the minimum of desired level and ceiling. The loan demand ( $\left.\operatorname{Loan}_{i t}^{d}\right)$, the maximum amount of credit available $\left(\operatorname{Loan}_{i t}^{s}\right)$ and the transaction equation $\left(\operatorname{Loan}_{i t}\right)$ of firm $i$ in period $t$ are:

$$
\begin{aligned}
& \operatorname{Loan}_{i t}^{d}=\beta_{0}^{d}+\beta_{1}^{d} \text { Activity }_{i t}^{d}+\beta_{2}^{d} \text { Size }_{i t}+\beta_{3}^{d} \text { Substitutes }_{i t}+\beta_{4}^{d} \text { Cost }_{i t}+u_{i t}^{d} \\
& \operatorname{Loan}_{i t}^{s}=\beta_{0}^{d}+\beta_{1}^{s} \text { Collateral }_{i t}+\beta_{2}^{d} \text { Default risk }_{i t}+u_{i t}^{s} \\
& \operatorname{Loan}_{i t}=\operatorname{Min}\left(\operatorname{Loan}_{i t}^{d}, \operatorname{Loan}_{i t}^{s}\right)
\end{aligned}
$$


As in Ogawa and Suzuki (2000), Atanasova and Wilson (2004), Shikimi (2005)

the amount of bank credit demanded is modelled as a function of the level or the expansion of firm activity, firm size, other sources of capital that are substitutes to bank loans, and the cost of bank credit. The maximum amount of credit available to a firm is modelled as a function of the firm's collateral and default risk. All level variables are expressed in terms of ratios to reduce heteroscedasticity. Thus, the size effect of "total assets" in the demand function above is estimated as part of the constant term, while the constant term is estimated as a coefficient of the reciprocal of total assets (the same logic is applied to the collateral effect of total assets and the constant term in the availability function). Firm activity is represented by the level of sales over the once lagged total assets. Both firm production capacity (total assets) and sales activity are expected to increase (the level of) loan demand. Cash flow and trade credit (as ratios of lagged total assets) are used to control for the effect of substitute funds on the demand for bank loans and, therefore, the expected signs of these variables are negative. The cost of bank credit is expressed as the percentage point spread between the interest rate paid ${ }^{14}$ by the firm and short-term prime rate and it is also expected to affect loan demand negatively ${ }^{15}$.

In the availability equation, a firm's "collateral" is proxied by the ratio of tangible fixed assets to lagged total assets and the expected sign is positive since the maximum amount supplied by a bank will increase with the level of collateral. We assume here that tangible assets are taken as collateral or, if not, are potentially attachable as collateral by

\footnotetext{
${ }^{14}$ The "interest paid" was computed from the income statement and divide it by bank loans outstanding. We implicitly assume that the year-end loan balance is roughly equal to the weighted average balance during the year.

${ }^{15}$ Since interest rates are central in this model, loan prices were alternatively introduced in levels instead or relative to short-term prime rate. The results remain statistically equal.
} 
the bank. Firms' default risk is measured by the ability to pay interest and the ability to pay short-term debt. The former is proxied by the operating profit/interest ratio, while the latter is proxied by the current assets/current liabilities ratio. A high operating profit/interest ratio or a high current assets/current liabilities ratio indicates that the default risk is low. Therefore, the expected signs of the collateral variable and the variables that indicate the ability to pay interest and short term debt are all positive. Both demand and availability equations contain $\log (G D P)$ to control for macroeconomic conditions across regional markets.

The simultaneous equations system shown in (9), (10) and (11) is estimated as a switching regression model using a full information maximum likelihood (FIML) routine, as shown by Maddala and Nelson (1974). The FIML routine employed also incorporates fixed effects to account for unobservable firm-level influences. Based upon the estimates of this system it is possible to compute the probability that loan demand exceed credit availability, as shown in Gersovitz (1980) and, therefore, to classify the sample into constrained and unconstrained firms. A formal specification of the computation of these probabilities is shown in Appendix B.

The estimated parameters of the disequilibrium model are shown in Table 5. All the variables have the expected signs and the overall significance of the equation, according to the log-likelihood is high. As shown by the demand equation parameters, a $1 \%$ increase in sales over total assets increases the desired demand of bank loans by $0.49 \%$ while a $1 \%$ increase in loan substitutes reduces loan demand by $1.39 \%$-in the case of internally generated cash flow- and $0.40 \%$-in the case of trade credit. Additionally, a $1 \%$ increase in the cost of funds is found to reduce the desired demand of 
bank loans by $0.47 \%$. As for the credit availability function, a $1 \%$ increase in collateral (measured by tangible fixed assets over total assets) increases the availability of loans by $0.45 \%$ and, similarly, a $1 \%$ rise in the ratio "current assets/current liabilities" (showing lower default risk) increase lending availability by $0.06 \%$.

\section{V.B. A classification of constrained firms from the disequilibrium model}

The estimations of the FIML disequilibrium model are employed to compute the probability that a given firm is financially constrained. The main results are summarized in Table 6, including a regional and sector breakdown. According to the estimated probabilities, a $33.90 \%$ of firms in the sample experienced borrowing constraints during the period. These values remain very stable over time. However, the results by regions and sectors reveal a substantial degree of heterogeneity across firms. In some regions such as Balearic Islands (28.81\%), Comunidad Valenciana (29.07\%) and Navarra (29.59\%)- the percentage of constrained firms is below $30 \%$, while in some others -such as Cantabria (39.88\%), Asturias (39.78\%), Castile and Leon (39.65\%), Extremadura (39.66\%), Galicia (39,23\%), Castile La Mancha (39\%) or Canary Islands (39\%)- the percentage of constraint firms is very close to $40 \%$. The sector breakdown even offers a higher degree of heterogeneity. In particular, the percentage of constrained firms is the lowest in sector such as transport services $(21.31 \%)$ and construction $(22.43 \%)$ while other industries such as the sale maintenance and repair of motor vehicles $(41.75 \%)$ or manufactures of textiles and dressing (41.73\%) show the higher percentage of constrained firms within the sample. All in all, these results confirm that the variability of 
financial conditions is very high for SMEs and that the regional perspective may help explaining some of the determinants of these constraints.

\section{V.C. Consistency with basic financing constraint variables: regional breakdown}

The classification of firms according to the probabilities of the disequilibrium model provides an additional measure of firms' financing constraints beyond the accounting ratios we employed earlier in the dynamic panel estimations. We use this classification of constrained firms to conduct two additional empirical analyses: (i) first, we analyze the consistency between the classification from the disequilibrium model and the financing constraint ratios; (ii) and, second, we use the disequilibrium model information in a probit model of firm financing constraints to estimate the marginal effects of market power and our other explanatory variables on the probability that a given firm is financially constrained.

Table 7 shows the correlations between each one of the financing constraints measures including a dummy variable that takes the value 1 if the firm is constrained according to the classification from the disequilibrium model and 0 otherwise. The correlations between the accounting ratios are high and show the expected signs. Additionally, the classification from the disequilibrium model also seems to be consistent with the accounting measures of financing constraints. The disequilibrium dummy variable exhibits a correlation of 0.77 with the variable "trade credit/total liabilities", 0.69 with "sales growth", 0.82 with "trade credit/tangible assets" and -0.73 with "loans/tangible assets". 
Our primary interest in this study is the effects of bank market competition on financing constraints. We explore this further in an analysis of the consistency of the borrowing constraint indicators by comparing the bank market characteristics that both constrained and unconstrained firms face. Table 8 shows the average values of the HHI of bank deposits and the Lerner index for constrained and unconstrained firms according to the accounting ratios and the classification from the disequilibrium model. In the case of the accounting ratios constrained and unconstrained firms are classified according to the sample distribution over and below the median values of these ratios. Not only do the accounting ratios reflect conflicting results based on the HHI concentration measure versus the Lerner index, but so does the disequilibrium model - and in the same direction. That is, constrained firms reflected lower levels of bank market concentration and higher values of the Lerner index across all measures. Similarly, Table 9 compares the percentage of constrained firms in the different regions with the average values of the HHI and Lerner Index in those regions, as well as the average bank credit risk, profitability and inefficiency. Again, those territories with the higher percentage of constrained firms exhibit lower levels of bank concentration and higher values of the Lerner index. These regions also exhibit higher levels of bank credit risk and inefficiency and lower bank profitability. 


\section{A probit model of firm borrowing constraints}

\section{A. Random effects estimation of a panel probit model}

The classification of firms from the disequilibrium model is employed as a binary choice, $Y$, where $Y=1$ corresponds to constrained firms and $Y=0$ to unconstrained firms. Equation (12) represents the basic estimating equation.

$$
\operatorname{Pr}(Y=1)=\Phi\left(\beta_{0}+\beta_{1} X_{F C}+\beta_{2} X_{B M}+\beta_{3} X_{E C}\right)
$$

where $\Phi$ is the cumulative normal distribution, $X_{F C}, X_{B M}, X_{E C}$ are vector explanatory variables representing, respectively, firm characteristics, bank market conditions and environmental control factors, and $\beta_{i}, i=0,1,2,3$ are vectors of coefficients.

Equation (12) is a binary choice probit equation. A common specification for discrete choice probit models for panel data is the error components model (Chamberlain, 1984) ${ }^{16}$ which splits the error into a time-invariant individual random effect, $\alpha_{i}$, and a time-varying idiosyncratic random error, $\varepsilon_{i t}$. Assuming that the distribution of $\varepsilon$ is symmetric with distribution function $F($.$) , we have:$

$P\left(y_{i t}=1\right)=P\left(\varepsilon_{i t}>X_{i t}^{\prime} \beta+\alpha_{i}\right)=F\left(X_{i t}^{\prime} \beta+\alpha_{i}\right)$

and assuming that $\alpha$ and $\varepsilon$ are normally distributed and independent of $X$ gives the random effects probit model.

Assuming that $\alpha$ and $\varepsilon$ are normally distributed and independent of $X$ gives the random effects probit model. $\alpha$ can be integrated out of (13) to give the sample log-likelihood function,

$$
\ln L=\sum_{i=1}^{n}\left\{\ln \int_{-\infty}^{+\infty} \prod_{t=1}^{T}\left(\Phi\left[d_{i t}\left(X_{i t}^{\prime} \beta+\alpha\right)\right] f(\alpha) d \alpha\right\}\right.
$$

\footnotetext{
${ }^{16}$ Note that the fixed effects models where not found to be adequate in this model according to a standard Hausman test.
} 
where $d_{i t}=2 y_{i t}-1$. This expression contains a univariate integral which can be approximated by Gauss-Hermite quadrature. Assuming $\left.\alpha \sim N\left(0, \sigma_{\alpha}^{2}\right)\right)$, the contribution of each individual to the sample likelihood function is,

$$
L_{i t}=\int_{-\infty}^{+\infty}\left(1 / \sqrt{2 \pi \sigma_{\alpha}^{2}}\right) \exp \left(-\alpha^{2} / 2 \sigma_{\alpha}^{2}\right)\{g(\alpha)\} d(\alpha)
$$

where $g(\alpha)=\prod_{t=1}^{T}\left(\Phi\left[d_{i t}\left(X_{i t}^{\prime} \beta+\alpha\right)\right]\right.$. Use the change of variables, $\alpha=\sqrt{2 \sigma_{\alpha}^{2}} \zeta$ to give,

$$
L_{i}=(1 / \sqrt{\pi}) \int_{-\infty}^{+\infty} \exp \left(-\zeta^{2}\right)\left\{g\left(\left(\sqrt{2 \sigma_{\alpha}^{2}}\right) \zeta\right)\right\} d(\zeta)
$$

As it takes the generic form $\int_{-\infty}^{+\infty} \exp \left(-\zeta^{2}\right) f(\zeta) d \zeta$, this expression is suitable for GaussHermite quadrature and can be approximated as a weighted sum,

$$
L_{i} \sim(1 / \sqrt{\pi}) \sum_{j=1}^{m} w_{j} g\left(\left(\sqrt{2 \sigma_{\alpha}^{2}}\right) a_{j}\right)
$$

where the weights $\left(w_{j}\right)$ and abscissae $\left(a_{j}\right)$ are tabulated in standard mathematical references and $m$ is the number of nodes or quadrature points (Butler and Moffitt, 1982).

\section{B. Probit results and marginal effects}

The results of the probit model are shown in Table $10 .^{17}$ The table reports both the parameter estimates and the marginal effect of each explanatory variable on the response probability. Marginal effects are reported in percentage points and computed at

\footnotetext{
${ }^{17}$ The results correspond to a random effect model accounting for autocorrelation. An AR(1) process is added to the random effects estimator to account for autocorrelation. The autocorrelation parameter $(\rho)$ was significant in all cases and, hence, we mainly rely on the results that account for autocorrelation. The number of points employed in the Hermite quadrature was 20, although the results remain consistent to other specifications.
} 
sample means. The model is estimated again using the HHI (specification I) and the Lerner index (specification II) as two alternative measures of competition. The results are quite in line with those obtained in the dynamic panel data estimations using accounting ratios as measures of borrowing constraints.

The overall significance of the probit estimations is high according to the loglikelihood values. As for firm characteristics, a 1\% increase in firm inefficiency and size seem to increase the probability of being financially constrained by $2.5 \%$ and $7.88 \%$, respectively. However, the marginal effect of firm profitability is $-3.14 \%$.

As in the dynamic panel model, the HHI and the Lerner index offer the opposite results. While a $1 \%$ increase in concentration is found to reduce the probability of being financially constrained by $35.42 \%$, a $1 \%$ increase in the Lerner index augments this probability by $11.3 \%$. Focusing just on the Lerner index regression (given the concern in the literature over the consistency of the HHI measure), we would conclude that higher bank market power has a negative effect on the probability that a firm is financially constrained. Moreover, this effect is found to be the larger among the explanatory factors of the model. Additionally, the marginal effect of average bank size $(-4.12 \%)$, credit risk $(-5.90 \%)$, the number of bank branches $(-0.009 \%)$ and bank profitability $(-4.09 \%)$ on the probability of being constrained are found to be negative, while the effect of bank inefficiency is found to be positive $(0.97 \%)$.

Among the environmental control variables, the negative marginal effect of GDP indicates that the probability that a firm is financially constrained falls by $-0.09 \%$ when GDP increases a $1 \%$. The marginal effects of the percentage of urban population $(0.91 \%)$ and the number of bankruptcies $(0.54 \%)$ are also found to be positive, suggesting that 
higher demand sophistication and financial instability result in a higher probability of firm credit rationing.

\section{Additional robustness checks: consistency of borrowing constraints and bank competition measures}

The empirical evidence shown in this study depends heavily on the validity of two types of indicators: (i) financing constraints measures; (ii) competition measures. So far, we have addressed concern about these indicators by using multiple measures of financing constraints (i.e., a set of four accounting ratios and a classification from the disequilibrium model) and two measures of market power. In this section we pursue additional robustness checks.

With regard to the financing constraint measures, we consider three additional caveats. As a first caveat, we follow Kaplan and Zingales (1997) and restrict the validity of the "sales growth" measure. They show that controlling for high values of sales growth seems to be an useful tool to control for "apparent" lower levels of financing constraints (simply due to extraordinary and temporary high sales growth). Considering this potential bias, we replicate the dynamic panel estimations including only those firms that exhibited a sales growth rate lower that $30 \%$. This restriction was applied not only to the equation where sales growth was the dependent variable but also to the rest of accounting measures ("trade credit/total liabilities", "trade credit/tangible assets" and "loans/tangible assets"). The results remain very similar to the original dynamic panel estimations ${ }^{18}$. Therefore, extraordinary sales growth levels are not found to introduce significant bias in our results. Second, since the results of the disequilibrium model have shown more

\footnotetext{
${ }^{18}$ These results are available upon request and are not shown here for simplicity.
} 
variation across sectors than across regions, we examine the extent to which the industrial structure of the region may affect the probability that a firm is financially constrained. Additional dynamic panel and probit estimations were then undertaken eliminating those firms belonging to the most and the least financially constrained sectors ${ }^{19}$. None of the conclusions on the determinants of firm borrowing constraints were modified according to the results obtained.

A third caveat refers to a debate that has garnered considerable attention in the firm financing literature. In particular, we examine the extent to which borrowing constraints are correlated with investment-cash flow correlations. The relationship between corporate investment and cash flow is, to a certain extent, a sort of a "black box". While Fazzari et al. (2000) suggest that financing constraints grow along with correlations between investment and cash-flow, Kaplan and Zingales (1997, 2000) suggested that investment-cash flow correlations are not necessarily monotonic in the degree of financing constraints. Importantly, most of the firms in our sample are nonquoted corporations. Hines and Thaler (1995) and Kaplan and Zingales (2000) suggested that investment-cash flow sensitivities can be, at least, partially caused by non-optimizing behaviour by managers. This behaviour would be more frequent in non-quoted SMEs since capital market discipline is not so strong in these firms. There is an alternative methodology (Bond and Meghir, 1994) to compute cash-flow investment correlations in unquoted firms, when the Tobin's-q is not available as a measure of firm's capital performance. The methodology consists of an Euler equation:

\footnotetext{
19 The firms belonging to the following sectors were excluded: manufactures of food products and beverages; manufactures of textiles and dressing; electricity, gas and water supply; construction; sale, maintenance and repair of motor vehicles; hotels and restaurants; transport services
} 
Investment $_{t} /$ capital $_{t-1}=\alpha^{*}$ Investment $_{t-1}+\beta^{*}$ Investment $^{2}+\chi^{*}$ Cash $_{\text {flow }} /$ capital $_{t-1}+$ $\delta^{*}$ sales $++\gamma^{*} d e b t^{2}$

The "investment" variable employed is the estimated value of coefficient " $\chi$ " is taken as the cash-flow investment correlation. To use this methodology, we have employed the same investment variable (Capital expenditures) employed by Kaplan and Zingales (1997) and Fazzari et al. (2000). In order to compare the cash-flow investment correlations with the level of financing constraints, the Euler equation has been estimated for the four quartiles going from less constrained (quartile 1) to most constrained firms (quartile 4) (using "trade credit/total liabilities" as an example),. The results are shown in Table 11. Interestingly, the cash-flow investment correlations are monotonic. They increase significantly from quartile 1 to quartile 2 and from quartile 2 to quartile 3 . However, they seem to maintain a very high value over the median (quartiles 3 and 4). Therefore, we may, at least, assume that a monotonic relationship holds between cash flow-investment correlation and firms financing constraints at least for firms below and over the median value of "trade credit/total liabilities". That is, in general our borrowing constraints are correlated with investment-cash flow correlations in the predicted way.

The second set of additional robustness check refers to the consistency of competition measures. Together with the HHI of bank deposits, various concentration measures were considered. First of all, we substituted the HHI of bank deposits with the one (CR1), three (CR3) and five (CR5) largest banks, respectively. The HHI was not robust to alternative specifications. Only the CR3 measure appeared to be negatively and significantly related to the financing constraint variables (as the HHI of bank deposits). The HHI of bank loans and of bank total assets were also included as concentration 
measures and only the former provided statistically significant results in line with those of the HHI of bank deposits. The inconsistency of the concentration measures castes some doubt on the accuracy of concentration as a measure of market power.

Various alternative variables were also tested as a robustness check for the Lerner index. A general concern about the use of the Lerner index is the problem of endogeneity since there are influences that may simultaneously affect both financing constraint measures and the Lerner index, such as the business cycle or some bank characteristics. As a first robustness check, only the numerator of this index - the mark-up of price over marginal costs - was included as a dependent variable. The aim was to abstract both prices and marginal costs (in levels) from business cycle influences, as in Maudos and Fernández de Guevara (2004). While the price of total assets is influenced by business cycle effects the net interest margin is not. The results were very similar to those obtained using the Lerner index. A second alternative measure to the Lerner index was the ratio "(interest revenue-interest expense)/total assets". This ratio proxies pricing behavior in both loan and deposit markets while the Lerner index is more inclusive (including all earning assets). As in the case of the Lerner index, interest margins over total assets were found to be positively and significantly related to borrowing constraints. A third robustness check for the Lerner index consists of including the price of total assets and marginal costs separately as explanatory variables. As expected, prices were found to be positively and significantly related to borrowing constraints while marginal costs were negatively and significantly related to the borrowing constraints variables. An additional concern with regard to endogeneity is the possible correlation between the Lerner index and other bank market characteristics such as bank profitability. However, the correlation 
coefficient between both variables (0.19) is too low as to impose separability in the estimation of the effects of bank market power and profitability in the regressions. The endogeneity of the Lerner index was also examined by 'instrumenting' the variable. In particular, the price variable in both the numerator and the denominator of the Lerner index was replaced by a 'predicted value' of this price. The predictions were obtained from a simple regression of the price variable of the level of bank capitalization (capital to total assets ratio) which is found to be correlated with bank prices but not with financing constraints ${ }^{20}$. The 'instrumented' Lerner index offer very similar results to those obtained using the standard Lerner index variable.

Finally, an additional test was undertaken to analyze the stability of the estimated parameters -in the dynamic panel equations- over time. Therefore, separate yearly crosssection OLS regressions were undertaken as a robustness check for dynamic panel estimations. The coefficients of all the explanatory factors remain relatively stable over time $^{21}$ with the HHI of bank deposits being the main exception. In particular, the HHI was found to be positively and significantly related to borrowing constraints in 1994 , 1995 and 1996, it was not statistically significant in 1997 and only achieved a negative sign from 1998 onwards. This result also suggests that the econometric outcomes from concentration measures are frequently spurious and that changes in bank market structure in recent years are better captured by looking at price to marginal costs indicators such as the Lerner index. ${ }^{22}$

\footnotetext{
${ }^{20}$ The correlation coefficient between bank capital and bank prices is found to be high and positive (0.7), while the correlation of bank capital on the financing constraint measures was not higher than 0.13 in any case.

${ }^{21}$ With poorer economic significance compared to dynamic panel outcomes.

${ }^{22}$ The overtime econometric inconsistency of the HHI as an explanatory variable of competitive behavior has been also shown for the US by Moore (1998).
} 


\section{Conclusions}

Corporate financing is one of the key pillars of the nexus between the financial sector and economic growth. For SMEs banks appear to play a particularly relevant role in providing external financing, since these firms are much more dependent on bank financing than their larger counterparts. This study analyzes a potentially critical factor in SME lending, the effect of bank market competition on firm borrowing constraints. Most previous studies of SME financing have confined their analysis to concentration indicators such as the Herfindahl Hisrchman index (HHI) as proxies of banking market competition. However, several studies have suggested that concentration measures are spurious indicators of bank market power and that other alternative measures based on direct estimations of prices and marginal costs such as the Lerner index are more accurate indicators of bank competition.

The relationship between bank competition and firm financing has been studied in the context of two main competing hypotheses. The market power view holds that concentrated banking markets are associated with less credit availability and a higher price for credit. However, an alternative view, the information hypothesis that has emerged during the last decade, argues that competitive banking markets can weaken relationship-building by depriving banks of the incentive to invest in soft information. Therefore, according to the information hypothesis, higher bank market power will reduce firm financing constraints. However, most of the studies that have found empirical support for the information hypothesis have relied on the HHI concentration indicators. 
In addition, most of them have studied this issue on data from the US where relationship lending is just one lending technology among many others.

This study offers new evidence on the relationship between bank market competition and firm financing constraints. Employing a large sample of firms and combining firm level data with bank level conditions in the markets where each firm operates, both concentration (HHI) and price to marginal costs indicators (specifically, the Lerner index) are analyzed as measures of bank competition. These measures are included along with other firm level, bank market and environmental control factors as determinants of firm borrowing constraints. Similarly, various measures of firm borrowing constraints are considered, including various accounting indicators and a classification from a disequilibrium model of bank lending. Our results are consistent across alternative specifications of borrowing constraints. In addition, they are consistent across alternative specifications of market power. However, they are not consistent across measures of bank market power. Specifically, the HHI and the Lerner index offer consistently opposite results. However, we find that the Lerner index is a considerably more accurate measure of competition. This lack of accuracy is in line with other findings in the banking literature that shed doubt on the strength of concentration as measure of market power (e.g., Berger, 1995; Rhoades, 1995; Jackson 1997; Hannan, 1997; Dick, 2005). Taking the Lerner index as the more reliable reference, our results show that bank market power increases firm financing constraints. Moreover, probit model results reveal that market power has the greater marginal effect on the probability that a firm is financially constrained among the posited set of explanatory factors. All in all, we argue that our results provide more support for the market structure hypothesis in 
bank lending relationships. Our findings also raise doubts about the value of relying exclusively, or even primarily, on concentration indicators as measures of bank competitive conditions in studies of bank-firm relationships. 


\section{$\underline{\text { References }}$}

Almeida, H. and M. Campello (2004): Financial Constraints, Asset Tangibility, and Corporate Investment, Working Paper, New York University and University of Illinois.

Angelini, P. and N. Cetorelli (1999): Bank Competition and Regulatory Reform: The Case of the Italian Banking Industry, Working Paper, Research Department, Federal Reserve Bank of Chicago, December (WP-99-32).

Arellano, M. and S. Bond (1991): "Some tests of specification for panel data: Monte Carlo evidence and an application to employment equation", Review of Economic Studies 58: $277-287$.

Arellano M. and O. Bover (1995): "Another Look at the Instrumental-Variable Estimation of Error-Components Models," Journal of Econometrics, 68: 29-51.

Atanasova, C.V. and N. Wilson (2004): 'Disequilibrium in the UK Corporate Loan Market', Journal of Banking and Finance, 28: 595-614.

Avery, R. B. and A. N. Berger (1991a) "Loan Commitments and Bank Risk Exposure" Journal of Banking and Finance, 15: 173-92.

Avery, R., Bostic, R. and K. Samolyk (1998): "The Role of Personal Wealth in Small Business Finance," Journal of Banking and Finance, 22: 1019-1061.

Bakker, M. H. R., Klapper, L. and G. F. Udell (2004): Financing Small- and MediumSize Enterprises with Factoring: Global Growth in Factoring-and Its Potential in Eastern Europe. Washington, DC: World Bank.

Becchetti, L. and J. Sierra (2003): "Bankruptcy risk and productive efficiency in manufacturing firms", Journal of Banking and Finance, 27: 2099-2120

Berg, S. A., and M. Kim (1994): "Oligopolistic Interdependence and the Structure of Production in Banking: An Empirical Evaluation", Journal of Money, Credit, and Banking, 26: 309-22.

Berger, A. N. (1995): "The Profit Structure Relationship in Banking. Tests of MarketPower and Efficient-Structure Hypotheses", Journal of Money, Credit, and Banking 27: 404-431.

Berger, A. N., (2004): Potential Competitive Effects of Basel II on Banks in SME Credit Markets in the United States, Finance and Economics Discussion Series paper 2004-12, Board of Governors of the Federal Reserve System. 
Berger, A. N. and T. Hannan (1989): “The Price-Concentration Relationship in Banking”. The Review of Economics and Statistics, Volume 71, Issue 2 291-299.

Berger, A.N., Hasan, I., Klapper, L.F. (2004): "Further evidence on the link between finance and growth: An international analysis of community banking and economic performance", Journal of Financial Services Research 25: 169-202.

Berger, A. N. and G. F. Udell (1990): "Collateral, loan quality, and bank risk," Journal of Monetary Economics, 25: 21-42.

Berger, A.N. and G. F. Udell (1992): "Some evidence on the empirical significance of credit rationing" Journal of Political Economy, 100: 1047-1077.

Berger, A. N. and G. F. Udell (1995): "Relationship lending and lines of credit in small firm finance", Journal of Business, 68: 351-381.

Berger, A. N. and G. F. Udell (1996). "Universal Banking and the Future of Small Business Lending," in by A. Saunders and I. Walter (eds.): Universal Banking: Financial System Design Reconsidered, Chicago: Irwin Professional Publishing: 558-627.

Berger, A.N. and G.F. Udell (1998): "The economics of small business finance: The roles of private equity and debt markets in the financial growth cycle," Journal of Banking and Finance, 22: 613-673

Berger, A. N., and G. F. Udell (2002): "Small Business Credit Availability and Relationship Lending: The Importance of Bank Organizational Structure," Economic Journal,112: 32-53.

Berger, A.N. and G.F. Udell (forthcoming): "A More Complete Conceptual Framework for SME Finance", Journal of Banking and Finance, forthcoming.

Berger, A. N., Rosen, R.J. and G. F. Udell (forthcoming): "Does Market Size Structure Affect Competition? The Case of Small Business Lending", Journal of Banking and Finance, forthcoming.

Berger, A. N., Demirguc-Kunt, A., Levine, R. and J. G. Haubrich (2004): "Bank Concentration and Competition: An Evolution in the Making', Journal of Money, Credit, and Banking, 36: 433-451.

Berger, A, N., Miller, N. H., Petersen, M. A., Rajan, R. and J. Stein (2005): "Does function follow organizational form? Evidence from the lending practices of large and small banks" Journal of Financial Economics, 76: 237-269

Berkovitch, E. and S. I. Greenbaum (1990): "The Loan Commitment as an Optimal Financing Contract", Journal of Financial and Quantitative Analysis 26: 83-95. 
Besanko, D. and A. Thakor, (1987a): "Collateral and rationing: Sorting Equilibria in monopolistic and competitive credit markets," International Economic Review, 28: 67189.

Besanko, D. and A. Thakor (1987b): "Competitive equilibrium in the credit market under asymmetric information" Journal of Economic Theory, 71: 291-99.

Bester, H. (1985): "Screening vs. Rationing in Credit Markets with Imperfect Information." American Economic Review, 75: 850-855.

Blundell, R., Bond, S. and F. Windmeijer (2000): Estimation in dynamic panel models: Improving on the performance on the standard GMM estimator, The Institute for Fiscal Studies, WP 00/12.

Bond, S., and C. Meghir (1994) "Dynamic investment models and the firm's financial policy.", Review of Economic Studies, 61:197-222.

Boot, A. and A. Thakor (2000): "Can Relationship Banking Survive Competition?", Journal of Finance, 55: 679-713.

Boot, A. W. A., Thakor, A.V. and G. F. Udell (1987): "Competition, Risk Neutrality and Loan Commitments", Journal of Banking and Finance 11: 449-471.

Boot, A., Thakor A. and G. F. Udell (1991): "Secured lending and default risk: Equilibrium analysis and policy implications and empirical results" Economic Journal, 101: 458-72.

Boyd, J. and E.C. Prescott (1986): "Financial Intermediary-Coalitions," Journal of Economic Theory, 38: 211-232.

Butler, J. and R. Moffitt, R. (1982): “A computationally efficient quadrature procedure for the one-factor multinomial probit model", Econometrica, 50: 761-764.

Caminal, R., and C. Matutes (2002): "Market Power and Banking Failures", International Journal of Industrial Organization 20: 1341-1361.

Carbó, S., Humphrey, D. and F. Rodríguez (2003): "Deregulation, bank competition and regional growth", Regional Studies 37: 227-237.

Carter, D. A., and J. E. McNulty (2005): Deregulation, Technological Change, and the Business Lending Performance of Large and Small Banks, mimeo.

Carter, D. A., McNulty, J.E. and J. A. Verbrugge (2004): "Do Small Banks have an Advantage in Lending? An Examination of Risk-adjusted Yields on Business Loans at Large and Small Banks", Journal of Financial Services Research, 25: 233-252. 
Cetorelli, N. and M. Gambera (2001): "Banking Market Structure, Financial Dependence and Growth: International Evidence from Industry Data", Journal of Finance, 56: 617648.

Chamberlain, G. (1984): "Panel data", in Griliches, Z. and M.D. Intrilgator (eds.), Handbook of Econometrics, North Holland:1247-1318.

Chan, Y.S. and G. Kanatas (1985): "Asymmetric valuation and the role of collateral in loan agreements", Journal of Money, Credit and Banking, 17: 85-95.

Cole, R. (1998). 'The importance of relationships to the availability of credit.' Journal of Banking and Finance, 22: 959-77.

Cole, R. A., Goldberg, L.G. and L. J. White (2004): "Cookie-cutter versus character: The Micro Structure of Small Business Lending by Large and Small Banks." Journal of Financial and Quantitative Analysis, 39: 227-251.

De Mello, J.M.P. (2004): Market Power and Availability of Credit: An Empirical Investigation of the Small Firms Credit Market, mimeo.

Degryse, H., and P. Cayseele (2000): 'Relationship lending within a bank-based system: Evidence from European small business data.' Journal of Financial Intermediation, 9: 90-109.

Dell'Arricia, G. and R. Marquez (2004): "Information and Bank Credit Allocation", Journal of Financial Economics, forthcoming.

Demirgüç-Kunt, A. and V. Maksimovic (1998): "Law, finance and firm growth”, Journal of Finance, 53: 2107-2137.

Demirgüç-Kunt, A. and V. Maksimovic (1999): "Institutions, Financial Markets and Firm Debt Maturity,” Journal of Financial Economics, 54, 66-97 .

Demirguc-Kunt, A., and V. Maksimovic (2001): Firms as Financial Intermediaries: Evidence from Trade Credit Data, Working Paper, World Bank and the University of Maryland.

Dick, A.A. (2005): "Market Size, Service Quality and Competition in Banking", Journal of Money, Credit and Banking, forthcoming.

Elsas, R. (2005): "Empirical Determinants of Relationship Lending", Journal of Financial Intermediation, 14: 32-57.

Elsas, R. and J.P. Krahnen (1998): "Is relationship lending special? Evidence from creditfile data in Germany", Journal of Banking and Finance, 22: 1283-1316.

Evans, D. and B. Jovanovic (1989): “An Estimated Model of Entrepreneurial Choice 
Under Liquidity Constraints", Journal of Political Economy, 97: 808-827.

Fazzari, S. M., Hubbard, R. G. and B. C. Petersen (2000): Financing Constraints and Corporate Investment: Response to Kaplan and Zingales" NBER Working Papers 5462.

Gersovitz, M. (1980): "On classification probabilities for the disequilibrium model", Journal of Econometrics, 14: 239-246.

Gorton, G., and J. Kahn (1997): The design of bank loan contracts, collateral, and renegotiation, University of Pennsylvania Working Paper.

Greenwald, B. and J. E. Stiglitz (1986): "Externalities in Economies with Imperfect Information and Incomplete Markets," Quarterly Journal of Economics , May: 229-264.

Hannan, T. H. (1991): "Bank commercial loan markets and the role of market structure: Evidence from surveys of commercial lending", Journal of Banking and Finance, 15: 133-149.

Hannan, T.H. (1997): Market share inequality, the number of competitors, and the HHI: An examination of bank pricing, Review of Industrial Organization 12: 23-35.

Hannan, T.H. y A. Berger (1991): "The Rigidity of Prices: Evidence from the Banking Industry", American Economic Review, 81: 938-945.

Harhoff, D. and T. Körting, T. (1998): "Lending relationships in Germany: Empirical results from survey data", Journal of Banking and Finance, 22: 1317-54.

Haynes, G., Ou, C. and R. Berney (1999): "Small Business Borrowing from Large and Small Banks" Proceedings of the Federal Reserve Bank of Chicago March: 287-293

Hines, J.R. Jr. and R. Thaler (1995): "The flypaper effect", Journal of Economic Perspectives, 9: 217-226.

Houston, J.F., and C. James (1998): "Do bank internal capital markets promote lending?", Journal of Banking and Finance, 22: 899-918.

Jackson, W. (1997): "Market structure and the speed of adjustment: Evidence of nonmonotonicity", Review of Industrial Organization, 12: 37-57.

James, C. (1987): "Some Evidence on the Uniqueness of Bank Loans," Journal of Financial Economics, 19: 217-235.

Jayaratne, J., and J.D. Wolken (1999): "How important are small banks to small business lending? New evidence from a survey to small businesses" Journal of Banking and Finance 23: 427-458. 
John, K., A. Lynch, and M. Puri (2003): "Credit ratings, collateral and loan characteristics: Implications for yield”, Journal of Business, 76: 371-410.

Kanatas, G. (1987): "Commercial Paper, Bank Reserve Requirements, and the Informational Role of Loan Commitments", Journal of Banking and Finance, 11: 425448.

Kaplan, S. and L. Zingales, 1997, "Do Financing Constraints Explain why Investment is Correlated with Cash Flow?” Quarterly Journal of Economics, 112, pp. 169-215.

Klapper, L., (1998): Short-term collateralization: Theory and evidence, New York University working paper.

Lamont, O., C. Polk and J. Saá-Requejo (2001): "Financial constraints and stock returns", Review of Financial Studies, 14: 529-54.

Lel, U. and G. Udell (2002): Financial Constraints, Start-up Firms and Personal Commitments, mimeo.

Lummer, S. L., and J.J. McConnell (1989). "Further Evidence on the Bank Lending Process and the Capital Market Response to Bank Loan Agreements," Journal of Financial Economics, 25: 99-122.

Maddala, G. S. (1983): Limited-Dependent and Qualitative Variables in Econometrics, Cambridge: Cambridge University Press.

Maddala, G. S. and F.D. Nelson (1974): "Maximum likelihood methods for models of markets in disequilibrium”, Econometrica 42: 1003-1030.

Maudos, J. and J. Fernandez de Guevara (2004): "Factors explaining the interest margin in the banking sectors of the European Union', Journal of Banking and Finance, 28: 2259-2281.

Melnik, A., S. E. Plaut (1986): "Loan Commitment Contracts, Terms of Lending, and Credit Allocation” Journal of Finance, 41: 425-435.

Mester, Loretta J., Leonard I. Nakamura, and Micheline Renault, "Checking Accounts and Bank Monitoring," Working Paper, Federal Reserve Bank of Philadelphia (October 1998).

Miwa, Y., J.M. Ramseyer (2005). "Trade Credit, Bank Loans, and Monitoring: Evidence from Japan." University of Tokyo Working Paper.

Moore, R. R. (1998), "Concentration, Technology, and Market Power in Banking: Is Distance Dead?", Financial Industry Studies, Federal Reserve Bank of Dallas, December, págs.1-24. 
Morgan, D.P. (1994): "Bank credit commitments, credit rationing, and monetary policy", Journal of Money, Credit, and Banking, 26: 87-101.

Morgan, D. P. (1998): "The Credit Effects of Monetary Policy: Evidence Using Loan Commitments." Journal of Money Credit and Banking, 30: 102-118.

Ogawa, K., K. Suzuki (2000): "Uncertainty and investment: some evidence from the panel data of Japanese manufacturing firms", Japanese Economic Review, 51: 170-192.

Ongena, S., and D.C. Smith (2001): "The duration of bank relationships", Journal of Financial Economics, 61: 449-475.

Petersen, M. A. and R. G. Rajan (1992): The Benefits of Firm-Creditor Relationships: Evidence from Small Business Data" University of Chicago Working Paper no. 362.

Petersen, Ml A. and R. G. Rajan (1994): "The Benefits of Lending Relationships: Evidence from Small Business Data", Journal of Finance, 49: 3-37.

Petersen, M.A. and R.G. Rajan (1995): "The effect of credit market competition on lending relationships", Quarterly Journal of Economics 110: 407-443.

Rajan, R. and L. Zingales (1998): "Financial dependence and growth", American Economic Review 88: 559-586.

Rhoades, S. A. (1995): "Market Share Inequality, the HHI, and Other Measures of the Firm-Composition of A Market", Review of Industrial Organization: 657-674.

Ribon, S. and O. Yosha (1999): Financial Liberalization and Competition in Banking: An Empirical Investigation, Tel Aviv University, Working Paper, 23-99.

Roberts, M. (1984): “Testing oligopolistic behavior”, International Journal of Industrial Organization, 2: 367-383.

Schiantarelli, F. (1995): "Financial Constraints and Investment: A Critical Review of Methodological Issues and International Evidence," in J. Peek and E. Rosengren (eds.), Federal Reserve Bank of Boston Conference Series No. 39.

Schmalensee, R. (1989): "Inter-industry Studies of Structure and Performance", in R. Schmalensee and R.D. Willig (eds.), Handbook of Industrial Organisation, 2: 951-1009. North-Holland, Amsterdam.

Scott J.A. and W.C. Dunkelberg (2005): "Bank Mergers and Small Firm Financing", Journal of Money, Credit and Banking, forthcoming. 
Shaffer, S. (1993): “A test of competition in Canadian Banking”, Journal of Money, Credit and Banking, 25: 49-61

Sharpe, S. A. (1990): “Asymmetric information, bank lending and implicit contracts: A stylized model of customer relationships", Journal of Finance, 55: 1069-1087.

Shikimi, M. (2005): Do Firms Benefit from Multiple Banking Relationships? Evidence from Small and Medium-Sized Firms in Japan, Discussion Paper Series, $\mathrm{n}^{\circ} 70$. Hitotsubashi University Research Unit for Statistical Analysis in Social Sciences.

Smith, C. and J. Warner (1979): "On financial contracting: an analysis of bond covenants", Journal of Financial Economics, 7: 117-161.

Sofianos, G., Wachtel, P. and A. Melnik (1990): "Loan Commitments and Monetary Policy," Journal of Banking and Finance, 14: 677-89.

Stein, J. C. (2002), "Information Production and Capital Allocation: Decentralized versus Hierarchical Firms" Journal of Finance, 57: 1891-1921.

Stiglitz, J.E. and A. Weiss (1981): "Credit rationing in markets with imperfect information". American Economic Review, 71:393-410.

Stulz, R. and H. Johnson (1985): "An analysis of secured debt", Journal of Financial Economics, 14: 501-512.

Swary, I. and G.F. Udell (1988): Information Production and the Secured Line of Credit, New York University working paper (March).

Thakor, A. V. and G. F. Udell (1987): "An Economic Rationale for the Pricing Structure of Bank Loan Commitments", Journal of Banking and Finance 11: 271-289.

Welch, I. (1997): "Why is bank debt senior? A theory of asymmetry and claim priority based on influence costs", Review of Financial Studies, 10: 1203-1236.

Zarutskie, R. (2003): Does Bank Competition Affect How Much Firms Can Borrow? New Evidence from the U.S., presented at Corporate Governance: Implications for Financial Services Firms, 39th Annual Conference on Bank Structure and Competition, Chicago, May 7-9, 2003. 


\section{Appendix A: Translog function to compute marginal costs in regional bank markets}

Bank marginal costs are computed using a single output (total assets) translog cost function with two cost share equations over 1994-2002:

$$
\begin{aligned}
& \ln T C=\alpha_{0} \alpha_{1} Q+\phi_{t} t^{\prime}+\frac{1}{2} \delta_{11} Q^{2}+\frac{1}{2} \phi_{1 t}\left[t^{\prime}\right]^{2}+\eta_{1 t} Q t^{\prime}+\rho_{11} Q\left(\ln R_{1}\right)+\rho_{12} Q\left(\ln R_{2}\right) \\
& +\left(-\rho_{11}-\rho_{12}\right) Q\left(\ln R_{3}\right)+\beta_{1} \ln R_{1}+\beta_{2} \ln R_{2}+\left(1-\lambda_{1}-\lambda_{2}\right)\left(\ln R_{3}\right) \\
& +\frac{1}{2}\left[\gamma_{11} \ln R_{1}^{2}+\gamma_{22} \ln R_{2}^{2}+\left[\left(\gamma_{11}+\gamma_{12}\right)+\left(\gamma_{12}+\gamma_{22}\right) \ln R_{3}^{2}\right]\right] \\
& +\gamma_{12} \ln R_{1}\left(\ln R_{2}\right)+\left(-\gamma_{11}-\gamma_{12}\right) \ln R_{1}\left(\ln R_{3}\right)+\left(\gamma_{12}-\gamma_{22}\right) \ln R_{2}\left(\ln R_{3}\right) \\
& +\mu_{1 t} t^{\prime} \ln R_{1}+\mu_{2 t} t^{\prime} \ln R_{2}+\mu_{3 t} t^{\prime} \ln R_{3}+\varepsilon
\end{aligned}
$$

$$
\begin{aligned}
& \mathrm{SH}_{1}=\rho_{11} Q+\beta_{1}+\gamma_{11} \ln R_{1}+\gamma_{12} \ln R_{2}+\left(-\gamma_{11}-\gamma_{12}\right) R_{3}+\mu_{1 k} t^{\prime} \\
& S H_{2}=\rho_{12} Q+\beta_{2}+\gamma_{22} \ln R_{2}+\gamma_{12} \ln R_{1}+\left(-\gamma_{22}-\gamma_{12}\right) R_{3}+\mu_{2 k} t^{\prime}
\end{aligned}
$$

where the standard symmetry, summation, and cross-equation restrictions are imposed and $\ln T C$ is the $\log$ of total operating and interest $\operatorname{cost} ; \ln Q$ is the $\log$ of the value of total assets (an indicator of total banking output); $\ln R i$ is the log of each one of the three input prices (deposit and other funding interest rate, average price of labor, and the average price of physical capital); SH1 and $\mathrm{SH} 2$ are the cost share equations of deposit and other funding interest expense and labor cost share (the cost share of physical capital is excluded); $t$ is a time dummy reflecting the effects of technical change on costs over time. 


\section{Appendix B: Computing probabilities from the disequilibrium model of firm financing constraints}

According to the results from the disequilibrium model in section V.B., a firm is defined as financially constrained in year $t$ if the probability that the desired amount of bank credit in year $t$ exceeds the maximum amount of credit available in the same year is greater than 0.5. Following Gersovitz (1980), the probability that firm will face a financial constraint in year is derived as follows:

$\operatorname{Pr}\left(\operatorname{loan}_{i t}^{d}>\operatorname{loan}_{i t}^{s}\right)=\operatorname{Pr}\left(X_{i t}^{d} \beta^{d}+u_{i t}^{d}>X_{i t}^{s} \beta^{s}+u_{i t}^{s}\right)=\Phi\left(\frac{X_{i t}^{d} \beta^{d}-X_{i t}^{s} \beta^{s}}{\sigma}\right)$

where $X_{i t}^{d}$ and $X_{i t}^{s}$ denote the variables that determine firms' loan demand and the maximum amount of credit available to firms, respectively. The error terms are assumed to be distributed normally, $\sigma^{2}=\operatorname{var}\left(u_{i t}^{d}-u_{i t}^{s}\right)$, and $\Phi($.$) is a standard normal distribution$ function. Since $E\left(\operatorname{loan}_{i t}^{d}\right)=X_{i t}^{d} \beta^{d}$ and $E\left(\operatorname{loan}_{i t}^{s}\right)=X_{i t}^{s} \beta^{s}, \operatorname{Pr}\left(\operatorname{loan}_{i t}^{d}>\operatorname{loan} n_{i t}^{s}\right)>0.5$, if and only if $E\left(\operatorname{loan}_{i t}^{d}\right)>E\left(\operatorname{loan}_{i t}^{s}\right)$. 


\begin{tabular}{|c|c|c|}
\hline REGION & FIRMS & OBSERVATIONS \\
\hline ANDALUSIA & 1.830 & 16.470 \\
\hline$A R A G O N$ & 1.810 & 16.290 \\
\hline ASTURIAS & 905 & 8.145 \\
\hline BALEARIC ISLANDS & 781 & 7.029 \\
\hline CANARY ISLANDS & 259 & 2.331 \\
\hline CANTABRIA & 173 & 1.557 \\
\hline CASTILE LA MANCHA & 1.750 & 15.750 \\
\hline CASTILE AND LEÓN & 963 & 8.667 \\
\hline CATALONIA & 8.767 & 78.903 \\
\hline COMUNIDAD VALENCIANA & 3.640 & 32.760 \\
\hline EXTREMADURA & 648 & 5.832 \\
\hline GALICIA & 1.800 & 16.200 \\
\hline MADRID & 3.660 & 32.940 \\
\hline MURCIA & 756 & 6.804 \\
\hline NAVARRA & 838 & 7.542 \\
\hline BASQUE COUNTRY & 1.816 & 16.344 \\
\hline RIOJA & 501 & 4.509 \\
\hline SECTOR & FIRMS & REGIONS \\
\hline MANUFACTURES OF FOOD PRODUCTS AND BEVERAGES & 2583 & 23247 \\
\hline MANUFACTURES OF TEXTILES AND DRESSING & 1917 & 17253 \\
\hline $\begin{array}{l}\text { MANUFACTURES OF WOOD, PAPER, PRINTING AND } \\
\text { RECORDED MEDIA PRODUCTS }\end{array}$ & 1564 & 14076 \\
\hline $\begin{array}{l}\text { MANUFACTURES OF CHEMICAL, PLASTIC, MINERAL AND } \\
\text { METAL PRODUCTS }\end{array}$ & 3296 & 29664 \\
\hline $\begin{array}{l}\text { MANUFACTURES OF MACHINERY AND EQUIPMENT AND } \\
\text { TRASNSPORT VEHICLES }\end{array}$ & 1947 & 17523 \\
\hline MANUFACTURES OF FURNITURE AND RECYCLING & 513 & 4617 \\
\hline ELECTRICITY, GAS AND WATER SUPPLY & 78 & 702 \\
\hline CONSTRUCTION & 4428 & 39852 \\
\hline SALE, MAINTENANCE AND REPAIR OF MOTOR VEHICLES & 1339 & 12051 \\
\hline WHOLESALE TRADE AND COMISSION TRADE & 6439 & 57951 \\
\hline HOTELS AND RESTAURANTS & 2484 & 22356 \\
\hline TRANSPORT SERVICES & 1272 & 11448 \\
\hline REAL STATE ACTIVITIES & 2236 & 20124 \\
\hline RENTING OF MACHINERY AND EQUIPMENT & 112 & 1008 \\
\hline COMPUTER AND RELATED ACTIVITIES & 203 & 1827 \\
\hline OTHER RETAIL TRADE PRODUCTS AND SERVICES & 471 & 4239 \\
\hline OTHER & 15 & 135 \\
\hline TOTAL & 30.897 & 278.073 \\
\hline
\end{tabular}




\section{Table 2. MEAN VALUES OF THE POSITED VARIABLES OVER TIME (1994-2002)}

\begin{tabular}{|c|c|c|c|c|c|c|c|c|c|c|}
\hline & 1994 & 1995 & 1996 & 1997 & 1998 & 1999 & 2000 & 2001 & 2002 & PERIOD \\
\hline \multicolumn{11}{|l|}{ Bank market power } \\
\hline HHI bank deposits & 0.12083 & 0.11733 & 0.11701 & 0.11356 & 0.10437 & 0.09645 & 0.08936 & 0.08314 & 0.07772 & 0.10220 \\
\hline Lerner index & 0.2102 & 0.2304 & 0.2403 & 0.2419 & 0.2412 & 0.2517 & 0.2532 & 0.2637 & 0.2641 & 0.2488 \\
\hline \multicolumn{11}{|l|}{$\begin{array}{l}\text { Other bank market } \\
\text { characteristics }\end{array}$} \\
\hline Average bank size & 8.0247 & 8.0928 & 8.3265 & 8.4085 & 8.4985 & 8.5123 & 8.6985 & 8.7158 & 8.8236 & 8.4215 \\
\hline Bank credit risk & 0.03352 & 0.02545 & 0.01059 & 0.00625 & 0.00232 & 0.00051 & 0.000223 & 0.00013 & 0.000114 & 0.00879 \\
\hline $\begin{array}{l}\text { Number of bank } \\
\text { branches }\end{array}$ & 3348 & 3450 & 3544 & 3590 & 3664 & 3702 & 3700 & 3687 & 3657 & 3594 \\
\hline Bank profitability & 0.00927 & 0.01125 & 0.01363 & 0.01819 & 0.02543 & 0.0182 & 0.0253 & 0.0331 & 0.0288 & 0.02035 \\
\hline Bank inefficiency & 0.71256 & 0.71053 & 0.70552 & 0.70523 & 0.6944 & 0.62015 & 0.6253 & 0.61002 & 0.56823 & 0.66133 \\
\hline \multicolumn{11}{|l|}{ Firm characteristics } \\
\hline $\begin{array}{l}\text { Trade credit/total } \\
\text { liabilities }\end{array}$ & 0.34166 & 0.34326 & 0.34234 & 0.35104 & 0.3498 & 0.34754 & 0.35155 & 0.34383 & 0.34530 & 0.34626 \\
\hline Sales growth & 0.38842 & 0.4721 & 0.6258 & 0.69692 & 0.71532 & 0.76181 & 0.73725 & 0.7825 & 0.91303 & 0.67702 \\
\hline $\begin{array}{l}\text { Trade credit/tangible } \\
\text { assets }\end{array}$ & 0.42586 & 0.43988 & 0.42824 & 0.44007 & 0.41583 & 0.41055 & 0.44201 & 0.43218 & 0.43020 & 0.43322 \\
\hline Loans/tangible assets & 0.21152 & 0.21337 & 0.20185 & 0.23597 & 0.22565 & 0.22219 & 0.23098 & 0.22436 & 0.22307 & 0.22688 \\
\hline Firm inefficiency & 0.86954 & 0.85442 & 0.82546 & 0.85517 & 0.83102 & 0.7858 & 0.8337 & 0.8882 & 0.81483 & 0.83979 \\
\hline Firm profitability & 0.0711 & 0.07656 & 0.07286 & 0.07116 & 0.07601 & 0.078 & 0.07135 & 0.06584 & 0.05432 & 0.07080 \\
\hline Firm size & 13.73 & 13.78 & 13.84 & 13.93 & 14.03 & 14.12 & 14.23 & 14.29 & 14.33 & 14.03 \\
\hline \multicolumn{11}{|l|}{$\begin{array}{l}\text { Environmental } \\
\text { regional control } \\
\text { variables }\end{array}$} \\
\hline$G D P$ & 41811 & 43643 & 44964 & 46400 & 48099 & 54074 & 52520 & 54016 & 55437 & 48996 \\
\hline Taxation & 0.21814 & 0.2152 & 0.2183 & 0.2163 & 0.2258 & 0.2352 & 0.1925 & 0.1935 & 0.2025 & 0.21305 \\
\hline $\begin{array}{l}\text { Percentage urban } \\
\text { population }\end{array}$ & 0.51252 & 0.52685 & 0.53713 & 0.53208 & 0.5412 & 0.5518 & 0.562 & 0.5727 & 0.5834 & 0.54663 \\
\hline $\begin{array}{l}\text { Number of } \\
\text { bankrupticies }\end{array}$ & 16 & 14 & 15 & 15 & 10 & 13 & 9 & 4 & 3 & 11 \\
\hline
\end{tabular}




\section{Table 3. SMEs Financing constraints and firm, bank market and environmental conditions (I). Dynamic panel data results.}

\begin{tabular}{|c|c|c|c|c|}
\hline \multirow[t]{2}{*}{$\begin{array}{r}\text { Dependent variable (financial } \\
\text { constraint) }\end{array}$} & \multicolumn{2}{|c|}{$\begin{array}{c}\text { Trade credit/(total } \\
\text { liabilities) }\end{array}$} & \multicolumn{2}{|c|}{ Sales growth } \\
\hline & (I) & (II) & (I) & (II) \\
\hline Constant & $\begin{array}{c}-5.0092 * * * \\
(0.000) \\
\end{array}$ & $\begin{array}{c}-5.3803 * * * \\
(0.000) \\
\end{array}$ & $\begin{array}{c}-4.9957 * * * \\
(0.000) \\
\end{array}$ & $\begin{array}{c}-5.0989^{* * *} \\
(0.000) \\
\end{array}$ \\
\hline Lagged dependent variable & $\begin{array}{c}-1.7410 * * * \\
(0.000) \\
\end{array}$ & $\begin{array}{c}-1.1637 * * * \\
(0.000) \\
\end{array}$ & $\begin{array}{c}-0.28255 \\
(0.383) \\
\end{array}$ & $\begin{array}{c}-0.56834 * * * \\
(0.000)\end{array}$ \\
\hline \multicolumn{5}{|l|}{ Bank market power } \\
\hline HHI bank deposits & $\begin{array}{c}-24.4223^{* * *} \\
(0.000) \\
\end{array}$ & - & $\begin{array}{c}18.3555^{* * *} \\
(0.000) \\
\end{array}$ & - \\
\hline Lerner index & - & $\begin{array}{c}0.0716^{* * *} \\
(0.000)\end{array}$ & - & $\begin{array}{c}-37.7462^{* *} \\
(0.015) \\
\end{array}$ \\
\hline \multicolumn{5}{|l|}{$\begin{array}{c}\text { Other bank market } \\
\text { characteristics }\end{array}$} \\
\hline Average bank size & $\begin{array}{c}-0.28390^{* * *} \\
(0.000)\end{array}$ & $\begin{array}{c}-0.06542 * * * \\
(0.000) \\
\end{array}$ & $\begin{array}{c}0.29065^{* * *} \\
(0.000)\end{array}$ & $\begin{array}{c}0.34853^{* * *} \\
(0.000)\end{array}$ \\
\hline Bank credit risk & $\begin{array}{c}-8.1582 * * * \\
(0.000) \\
\end{array}$ & $\begin{array}{c}-27.1408 * * * \\
(0.000) \\
\end{array}$ & $\begin{array}{l}-8.4058 \\
(0.205) \\
\end{array}$ & $\begin{array}{c}1.28231 \\
(0.910) \\
\end{array}$ \\
\hline Number of bank branches & $\begin{array}{c}-0.0036 * * * \\
(0.000) \\
\end{array}$ & $\begin{array}{c}-0.00558^{* * *} \\
(0.000) \\
\end{array}$ & $\begin{array}{c}0.00347 * * * \\
(0.003)\end{array}$ & $\begin{array}{c}0.0057^{* * * *} \\
(0.000)\end{array}$ \\
\hline Bank profitability & $\begin{array}{c}-4.2153 * * * \\
(0.000) \\
\end{array}$ & $\begin{array}{c}-3.0651^{* *} \\
(0.015) \\
\end{array}$ & $\begin{array}{c}-1.7013 * * * \\
(0.000)\end{array}$ & $\begin{array}{c}-0.7377^{* * *} \\
(0.003)\end{array}$ \\
\hline Bank inefficiency & $\begin{array}{c}0.0399 * * * \\
(0.000)\end{array}$ & $\begin{array}{c}0.04575^{* * *} \\
(0.008)\end{array}$ & $\begin{array}{c}-0.0254 * * * \\
(0.000)\end{array}$ & $\begin{array}{c}-0.03408 * * * \\
(0.004)\end{array}$ \\
\hline \multicolumn{5}{|l|}{ Firm characteristics } \\
\hline Firm inefficiency & $\begin{array}{c}-0.02573 \\
(0.172) \\
\end{array}$ & $\begin{array}{c}0.0586^{* *} \\
(0.046)\end{array}$ & $\begin{array}{r}-0.0513 \\
(0.675) \\
\end{array}$ & $\begin{array}{c}-0.05244 \\
(0.488) \\
\end{array}$ \\
\hline Firm profitability & $\begin{array}{l}0.0929 \\
(0.329) \\
\end{array}$ & $\begin{array}{c}-0.06610^{*} \\
(0.054) \\
\end{array}$ & $\begin{array}{r}-1.5242 \\
(0.132) \\
\end{array}$ & $\begin{array}{l}2.5287 \\
(0.325) \\
\end{array}$ \\
\hline Firm size & $\begin{array}{c}0.12027^{* * *} \\
(0.000) \\
\end{array}$ & $\begin{array}{c}0.38549^{* * *} \\
(0.000)\end{array}$ & $\begin{array}{c}-0.2625^{* *} \\
(0.012) \\
\end{array}$ & $\begin{array}{c}-0.45281^{* *} \\
(0.022) \\
\end{array}$ \\
\hline \multicolumn{5}{|l|}{$\begin{array}{c}\text { Environmental regional control } \\
\text { variables } \\
\end{array}$} \\
\hline$G D P$ & $\begin{array}{c}-0.35 \mathrm{E}-05^{* * *} \\
(0.000) \\
\end{array}$ & $\begin{array}{c}-0.25 \mathrm{E}-05^{* * *} \\
(0.000) \\
\end{array}$ & $\begin{array}{c}0.10 \mathrm{E}-05^{* *} \\
(0.021)\end{array}$ & $\begin{array}{c}0.23 \mathrm{E}-05^{* * *} \\
(0.000)\end{array}$ \\
\hline Taxation & $\begin{array}{c}-0.00014 \\
(0.670) \\
\end{array}$ & $\begin{array}{c}0.00027 * * \\
(0.022)\end{array}$ & $\begin{array}{c}-0.0059^{*} \\
(0.068) \\
\end{array}$ & $\begin{array}{c}-0.0030^{*} \\
(0.090) \\
\end{array}$ \\
\hline Percentage urban population & $\begin{array}{c}2.8449 * * * \\
(0.000)\end{array}$ & $\begin{array}{c}9.9921^{* * *} \\
(0.000)\end{array}$ & $\begin{array}{c}-12.2065^{* * *} \\
(0.000) \\
\end{array}$ & $\begin{array}{c}-5.5814^{* * *} \\
(0.002) \\
\end{array}$ \\
\hline Number of bankrupticies & $\begin{array}{c}0.06977 * * * \\
(0.000) \\
\end{array}$ & $\begin{array}{c}0.09627 * * * \\
(0.000)\end{array}$ & $\begin{array}{c}-0.0345 * * * \\
(0.008)\end{array}$ & $\begin{array}{c}-0.06417 * * * \\
(0.008)\end{array}$ \\
\hline$F$-statistic & 0.0166 & 0.015 & 0.021 & 0.020 \\
\hline Sargan test & 0.137 & 0.163 & 0.131 & 0.129 \\
\hline Observations & 278.073 & 278.073 & 278.073 & 278.073 \\
\hline Number of firms & 30.897 & 30.897 & 30.897 & 30.897 \\
\hline
\end{tabular}

* Statistically significant at $10 \%$ level

** Statistically significant at 5\% level

*** Statistically significant at $1 \%$ level 


\section{Table 4. SMEs Financing constraints and firm, bank market and environmental conditions (II). Dynamic panel data results.}

\begin{tabular}{|c|c|c|c|c|}
\hline \multirow[t]{2}{*}{$\begin{array}{r}\text { Dependent variable (financial } \\
\text { constraint) }\end{array}$} & \multicolumn{2}{|c|}{ Trade credit/tangible assets } & \multicolumn{2}{|c|}{ Loans/tangible assets } \\
\hline & (I) & (II) & (I) & (II) \\
\hline Constant & $\begin{array}{c}-5.0239 * * * \\
(0.000) \\
\end{array}$ & $\begin{array}{c}-4.9247 * * * \\
(0.000)\end{array}$ & $\begin{array}{c}-5.0172 * * * \\
(0.000) \\
\end{array}$ & $\begin{array}{c}-4.9030^{* * *} \\
(0.000)\end{array}$ \\
\hline Lagged dependent variable & $\begin{array}{c}-0.13241 * * \\
(0.044)\end{array}$ & $\begin{array}{c}-0.17130 * \\
(0.063)\end{array}$ & $\begin{array}{c}-0.35289 * * \\
(0.014)\end{array}$ & $\begin{array}{c}-0.7580 * * * \\
(0.002)\end{array}$ \\
\hline \multicolumn{5}{|l|}{ Bank market power } \\
\hline HHI bank deposits & $\begin{array}{c}-20.1553 * * * \\
(0.000) \\
\end{array}$ & - & $\begin{array}{c}18.5966 * * * \\
(0.003)\end{array}$ & - \\
\hline Lerner index & - & $\begin{array}{c}0.18337 * * \\
(0.044)\end{array}$ & - & $\begin{array}{c}-0.07285^{* *} \\
(0.017)\end{array}$ \\
\hline \multicolumn{5}{|l|}{$\begin{array}{c}\text { Other bank market } \\
\text { characteristics }\end{array}$} \\
\hline Average bank size & $\begin{array}{c}-0.26856^{* * * *} \\
(0.000)\end{array}$ & $\begin{array}{c}-0.14254 * * * \\
(0.000)\end{array}$ & $\begin{array}{c}0.28110^{* * *} \\
(0.000)\end{array}$ & $\begin{array}{c}0.54300^{* * *} \\
(0.000)\end{array}$ \\
\hline Bank credit risk & $\begin{array}{c}-27.5571^{* * * *} \\
(0.000) \\
\end{array}$ & $\begin{array}{c}-3.7128^{* *} \\
(0.044) \\
\end{array}$ & $\begin{array}{c}-24.3412 * * * \\
(0.000) \\
\end{array}$ & $\begin{array}{c}-23.6742 * * * \\
(0.000) \\
\end{array}$ \\
\hline Number of bank branches & $\begin{array}{c}-0.0088^{* *} \\
(0.046)\end{array}$ & $\begin{array}{c}-0.00120 * * * \\
(0.000)\end{array}$ & $\begin{array}{c}-0.0069 * * * \\
(0.037)\end{array}$ & $\begin{array}{c}0.00438 * * * \\
(0.000)\end{array}$ \\
\hline Bank profitability & $\begin{array}{c}-5.6065^{* * *} \\
(0.001) \\
\end{array}$ & $\begin{array}{c}-0.45365 \\
(0.670) \\
\end{array}$ & $\begin{array}{c}4.6456^{* * *} \\
(0.000)\end{array}$ & $\begin{array}{c}4.8282 * * * \\
(0.000)\end{array}$ \\
\hline Bank inefficiency & $\begin{array}{c}0.07298 * * * \\
(0.001)\end{array}$ & $\begin{array}{c}0.0757 * * * \\
(0.009) \\
\end{array}$ & $\begin{array}{c}0.02623 \\
(0.312) \\
\end{array}$ & $\begin{array}{l}0.0236 \\
(0.696) \\
\end{array}$ \\
\hline \multicolumn{5}{|l|}{ Firm characteristics } \\
\hline Firm inefficiency & $\begin{array}{c}0.03765^{* * *} \\
(0.003)\end{array}$ & $\begin{array}{c}0.09726^{* * *} \\
(0.000)\end{array}$ & $\begin{array}{c}-0.04127 * * \\
(0.016) \\
\end{array}$ & $\begin{array}{c}-0.13153^{* * *} \\
(0.000) \\
\end{array}$ \\
\hline Firm profitability & $\begin{array}{r}-0.99245 \\
(0.1118) \\
\end{array}$ & $\begin{array}{c}-0.40065 \\
(0.551) \\
\end{array}$ & $\begin{array}{r}-0.8333 \\
(0.210) \\
\end{array}$ & $\begin{array}{c}-1.1030 \\
(0.150) \\
\end{array}$ \\
\hline Firm size & $\begin{array}{c}0.30278^{* * * *} \\
(0.000)\end{array}$ & $\begin{array}{c}0.59241^{* * * *} \\
(0.000)\end{array}$ & $\begin{array}{c}-0.2894 * * * \\
(0.000)\end{array}$ & $\begin{array}{c}-0.71787^{* * * *} \\
(0.000)\end{array}$ \\
\hline \multicolumn{5}{|l|}{$\begin{array}{c}\text { Environmental regional } \\
\text { control variables }\end{array}$} \\
\hline$G D P$ & $\begin{array}{c}-0.74 \mathrm{E}-05^{*} \\
(0.085)\end{array}$ & $\begin{array}{c}-0.16 \mathrm{E}-05^{* *} \\
(0.028)\end{array}$ & $\begin{array}{c}0.24 \mathrm{E}-05^{* *} \\
(0.021)\end{array}$ & $\begin{array}{c}0.67 \mathrm{E}-06^{* * *} \\
(0.007)\end{array}$ \\
\hline Taxation & $\begin{array}{l}0.00011 \\
(0.938) \\
\end{array}$ & $\begin{array}{l}-0.0075 \\
(0.237) \\
\end{array}$ & $\begin{array}{l}-0.0021 \\
(0.174) \\
\end{array}$ & $\begin{array}{c}-0.0033^{* *} \\
(0.046)\end{array}$ \\
\hline Percentage urban population & $\begin{array}{c}3.3743^{* *} \\
(0.026)\end{array}$ & $\begin{array}{c}19.6443^{* * *} \\
(0.000)\end{array}$ & $\begin{array}{l}-3.3508 \\
(0.121) \\
\end{array}$ & $\begin{array}{c}-20.8820^{* * *} \\
(0.000) \\
\end{array}$ \\
\hline Number of bankrupticies & $\begin{array}{c}0.04876^{* * *} \\
(0.000)\end{array}$ & $\begin{array}{c}0.07875^{* * *} \\
(0.000)\end{array}$ & $\begin{array}{c}0.04158^{* * *} \\
(0.000) \\
\end{array}$ & $\begin{array}{c}0.03142^{* * *} \\
(0.000)\end{array}$ \\
\hline$F$-statistic & 0.022 & 0.025 & 0.027 & 0.021 \\
\hline Sargan test & 0.181 & 0.174 & 0.140 & 0.161 \\
\hline Observations & 278.073 & 278.073 & 278.073 & 278.073 \\
\hline Number of firms & 30.897 & 30.897 & 30.897 & 30.897 \\
\hline
\end{tabular}

\footnotetext{
* Statistically significant at $10 \%$ level

** Statistically significant at 5\% level

*** Statistically significant at 1\% level
} 


\section{Table 5. Estimated parameters of a disequilibrium model.}

Switching regression model estimated by full information maximum likelihood (FIML) with fixed effects

p-values in parenthesis

\begin{tabular}{|c|c|c|}
\hline Desired demand for bank loans & Coefficient & Std. Error \\
\hline Reciprocal of total assets & $\begin{array}{c}119038.0 * * * \\
(0.000)\end{array}$ & 1073.10 \\
\hline Sales/total assets (t-1) & $\begin{array}{c}0.48031^{* * *} \\
(0.000)\end{array}$ & 0.01 \\
\hline Cash-flow/total assets(t-1) & $\begin{array}{c}-1.39319^{* * * *} \\
(0.000) \\
\end{array}$ & 0.06 \\
\hline Trade credit/total assets(t-1) & $\begin{array}{c}-0.40445^{* * * *} \\
(0.000)\end{array}$ & 0.01 \\
\hline Loan interest rate minus short term prime rate & $\begin{array}{c}-0.47646^{* * * *} \\
(0.000) \\
\end{array}$ & 0.09 \\
\hline $\log (G D P)$ & $\begin{array}{c}0.25973^{* *} \\
(0.013) \\
\end{array}$ & 0.10 \\
\hline \multicolumn{3}{|l|}{ Availability of bank loans } \\
\hline Reciprocal of total assets & $\begin{array}{c}84518.2 * * * \\
(0.000)\end{array}$ & 2038.85 \\
\hline Tangible fixed assets/total assets(t-1) & $\begin{array}{c}0.45201 * * * \\
(0.000) \\
\end{array}$ & 0.01 \\
\hline Operating profit/interest $(t-1)$ & $\begin{array}{c}0.000030 \\
(0.994)\end{array}$ & 0.01 \\
\hline Current assets/current liabilities & $\begin{array}{c}0.06925 * * * \\
(0.000) \\
\end{array}$ & 0.01 \\
\hline $\log (G D P)$ & $\begin{array}{c}-0.02896 \\
(0.684)\end{array}$ & 0.07 \\
\hline S.D. of demand equation & $\begin{array}{c}1.5548 * * * \\
(0.000)\end{array}$ & 0.01 \\
\hline S.D. of availability equation & $\begin{array}{c}0.9045^{* * *} \\
(0.000)\end{array}$ & 0.01 \\
\hline Correlation coefficient & $\begin{array}{c}0.6511^{* * * *} \\
(0.000)\end{array}$ & 0.09 \\
\hline Log likelihood & \multicolumn{2}{|c|}{148979} \\
\hline Observations & \multicolumn{2}{|c|}{278.073} \\
\hline Number of firms & \multicolumn{2}{|c|}{30.897} \\
\hline
\end{tabular}

* Statistically significant at 10\% level

** Statistically significant at 5\% level

*** Statistically significant at $1 \%$ level 


\section{Table 6. Percentage of borrowing constrained firms}

\begin{tabular}{|c|c|}
\hline Time & $\%$ \\
\hline Entire period (1994-2002) & 33,90 \\
\hline 1994 & 34,62 \\
\hline 1995 & 31,88 \\
\hline 1996 & 34,22 \\
\hline 1997 & 32,30 \\
\hline 1998 & 34,25 \\
\hline 1999 & 34,93 \\
\hline 2000 & 35,16 \\
\hline 2001 & 34,14 \\
\hline 2002 & 33,60 \\
\hline Region & $\%$ \\
\hline ANDALUSIA & 39,23 \\
\hline$A R A G O N$ & 38,41 \\
\hline ASTURIAS & 39,78 \\
\hline BALEARIC ISLANDS & 28,81 \\
\hline CANARY ISLANDS & 39,00 \\
\hline CANTABRIA & 39,88 \\
\hline CASTILE LA MANCHA & 39,00 \\
\hline CASTILE AND LEÓN & 39,65 \\
\hline CATALONIA & 32,01 \\
\hline COMUNIDAD VALENCIANA & 29,07 \\
\hline EXTREMADURA & 39,66 \\
\hline GALICIA & 39,23 \\
\hline MADRID & 31,37 \\
\hline MURCIA & 38,23 \\
\hline NAVARRA & 29,59 \\
\hline BASQUE COUNTRY & 31,21 \\
\hline RIOJA & 32,39 \\
\hline Sector & $\%$ \\
\hline MANUFACTURES OF FOOD PRODUCTS AND BEVERAGES & 26,29 \\
\hline MANUFACTURES OF TEXTILES AND DRESSING & 41,73 \\
\hline $\begin{array}{l}\text { MANUFACTURES OF WOOD, PAPER, PRINTING AND RECORDED MEDIA } \\
\text { PRODUCTS }\end{array}$ & 39,00 \\
\hline MANUFACTURES OF CHEMICAL, PLASTIC, MINERAL AND METAL PRODUCTS & 35,29 \\
\hline $\begin{array}{l}\text { MANUFACTURES OF MACHINERY AND EQUIPMENT AND TRASNSPORT } \\
\text { VEHICLES }\end{array}$ & 25,22 \\
\hline MANUFACTURES OF FURNITURE AND RECYCLING & 34,89 \\
\hline ELECTRICITY, GAS AND WATER SUPPLY & 24,36 \\
\hline CONSTRUCTION & 22,43 \\
\hline SALE, MAINTENANCE AND REPAIR OF MOTOR VEHICLES & 41,75 \\
\hline WHOLESALE TRADE AND COMISSION TRADE & 39,85 \\
\hline HOTELS AND RESTAURANTS & 48,43 \\
\hline TRANSPORT SERVICES & 21,31 \\
\hline REAL STATE ACTIVITIES & 30,46 \\
\hline RENTING OF MACHINERY AND EQUIPMENT & 32,14 \\
\hline COMPUTER AND RELATED ACTIVITIES & 37,44 \\
\hline OTHER RETAIL TRADE PRODUCTS AND SERVICES & 30,36 \\
\hline OTHER & 33,33 \\
\hline
\end{tabular}




\section{Table 7. Firm financing constraints criteria. Correlations}

\begin{tabular}{l|l|c|c|c|c|}
\hline Mean values & \multicolumn{5}{|c|}{ Trade } \\
\hline Criterion & $\begin{array}{l}\text { Trade } \\
\text { credit/ total } \\
\text { liabilities }\end{array}$ & $\begin{array}{c}\text { Sales } \\
\text { growth }\end{array}$ & $\begin{array}{c}\text { La) } \\
\text { tangible } \\
\text { assets }\end{array}$ & $\begin{array}{l}\text { Loans/ } \\
\text { tangible } \\
\text { assets }\end{array}$ & $\begin{array}{c}\text { Disequilibrium } \\
\text { model } \\
\text { (constrained } \\
\text { firms) }\end{array}$ \\
\hline Trade credit/total liabilities & 1.00 & -0.64 & 0.84 & -0.73 & 0.77 \\
\hline Sales growth & -0.64 & 1.00 & -0.63 & 0.82 & -0.69 \\
\hline Trade credit/tangible assets & 0.84 & -0.63 & 1.00 & -0.74 & 0.82 \\
\hline Loans/tangible assets & -0.73 & 0.82 & -0.74 & 1.00 & -0.73 \\
\hline $\begin{array}{l}\text { Disequilibrium model (constrained } \\
\text { firms) }\end{array}$ & 0.77 & -0.69 & 0.82 & -0.73 & 1.00 \\
\hline
\end{tabular}

\section{Table 8. Firm financing constraints, bank concentration and bank Lerner index}

\begin{tabular}{|c|c|c|c|c|}
\hline & BANK HH & basis points) & BANK LERI & R INDEX (\%) \\
\hline Criterion & $\begin{array}{c}\text { Constrained } \\
\text { firms }\end{array}$ & $\begin{array}{c}\text { Unconstrained } \\
\text { firms }\end{array}$ & $\begin{array}{c}\text { Constrained } \\
\text { firms }\end{array}$ & $\begin{array}{c}\text { Unconstrained } \\
\text { firms }\end{array}$ \\
\hline Trade credit/total liabilities ${ }^{\text {(a) }}$ & 0.1009 & 0.1040 & 22.62 & 16.96 \\
\hline Sales growth ${ }^{(\mathrm{a})}$ & 0.1002 & 0.1105 & 20.07 & 15.08 \\
\hline Trade credit/tangible assets (a) & 0.0928 & 0.1108 & 21.73 & 16.11 \\
\hline Loans/tangible assets (a) & 0.1012 & 0.1145 & 21.03 & 15.73 \\
\hline Disequilibrium model & 0.1001 & 0.1156 & 20.01 & 16.04 \\
\hline
\end{tabular}




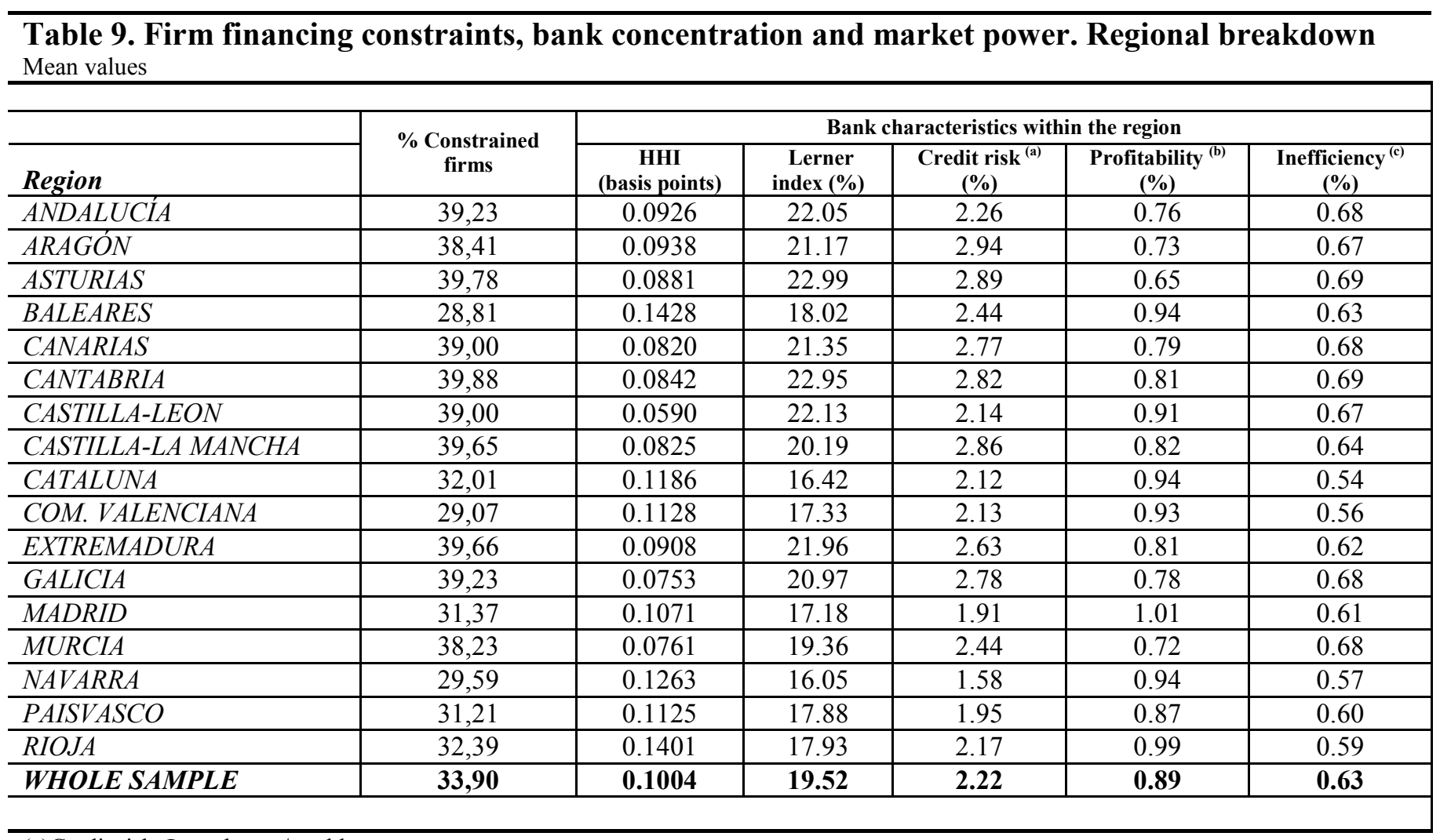

(a)Credit risk: Loan losses/total loans

(b) Profitability: Return on assets (ROA)

(c) Inefficiency: operating costs/gross income 


\section{Table 10. SMEs Financing constraints and firm, bank market and environmental conditions. PROBIT random effects panel data results.}

Dependent variable $=1$ if the firm is financially constrained, 0 otherwise

number of points in Hermite quadrature $=20$

p-values in parenthesis

\begin{tabular}{|c|c|c|c|c|}
\hline & \multicolumn{2}{|c|}{ (I) } & \multicolumn{2}{|c|}{ (II) } \\
\hline & Esitmate & $\begin{array}{c}\text { Economic } \\
\text { significance } \\
\left(\text { marginal effect }^{\mathrm{a}}\right)\end{array}$ & Esitmate & $\begin{array}{c}\text { Economic } \\
\text { significance } \\
\left.\text { (marginal effect }^{\mathrm{a}}\right)\end{array}$ \\
\hline Constant & $\begin{array}{c}3.4174 * * * \\
(0.000)\end{array}$ & - & $\begin{array}{c}3.3164 * * * \\
(0.000)\end{array}$ & - \\
\hline \multicolumn{5}{|l|}{ Bank market power } \\
\hline HHI bank deposits & $\begin{array}{c}-0.39593 * * \\
(0.010)\end{array}$ & -35.42 & - & - \\
\hline Lerner index & - & - & $\begin{array}{c}0.02889^{* * *} \\
(0.000)\end{array}$ & 11.3 \\
\hline \multicolumn{5}{|l|}{ Other bank market characteristics } \\
\hline Average bank size & $\begin{array}{c}-0.40918^{* *} \\
(0.042)\end{array}$ & -4.12 & $\begin{array}{c}-0.62672^{* *} \\
(0.041)\end{array}$ & -4.26 \\
\hline Bank credit risk & $\begin{array}{c}-2.5549 * * * \\
(0.000)\end{array}$ & -4.62 & $\begin{array}{c}-2.1420 * * * \\
(0.000)\end{array}$ & -5.83 \\
\hline Number of bank branches & $\begin{array}{c}-0.00016^{* * * *} \\
(0.000)\end{array}$ & -0.0085 & $\begin{array}{c}-0.000159 * * * \\
(0.001)\end{array}$ & -0.0091 \\
\hline Bank profitability & $\begin{array}{c}-0.281142 * * \\
(0.032)\end{array}$ & -9.67 & $\begin{array}{c}-0.13310 \\
(0.315)\end{array}$ & -4.01 \\
\hline Bank inefficiency & $\begin{array}{c}0.08840 * * * \\
(0.005)\end{array}$ & 0.56 & $\begin{array}{c}0.01699 * * * \\
(0.000)\end{array}$ & 0.98 \\
\hline \multicolumn{5}{|l|}{ Firm characteristics } \\
\hline Firm inefficiency & $\begin{array}{c}0.03413^{* * *} \\
(0.004)\end{array}$ & 2.57 & $\begin{array}{c}0.04880^{* *} \\
(0.011)\end{array}$ & 6.90 \\
\hline Firm profitability & $\begin{array}{c}-0.09564 * * * \\
(0.000)\end{array}$ & -3.13 & $\begin{array}{c}-0.09535 * * * \\
(0.000)\end{array}$ & -4.04 \\
\hline Firm size & $\begin{array}{c}0.27370^{* * *} \\
(0.000)\end{array}$ & 7.85 & $\begin{array}{c}0.26986^{* * *} \\
(0.000)\end{array}$ & 7.82 \\
\hline \multicolumn{5}{|l|}{ Environmental regional control variables } \\
\hline$G D P$ & $\begin{array}{c}-0.13 \mathrm{E}-05^{* * *} \\
(0.000) \\
\end{array}$ & -0.067 & $\begin{array}{c}-0.15 \mathrm{E}-05^{* * *} \\
(0.000) \\
\end{array}$ & -0.10 \\
\hline Taxation & $\begin{array}{l}0.00040 \\
(0.550) \\
\end{array}$ & 0.00097 & $\begin{array}{l}0.00047 \\
(0.488) \\
\end{array}$ & 0.00010 \\
\hline Percentage urban population & $\begin{array}{c}0.20669^{* * *} \\
(0.000)\end{array}$ & 0.95 & $\begin{array}{c}0.22799 * * * \\
(0.005)\end{array}$ & 0.91 \\
\hline Number of bankrupticies & $\begin{array}{c}0.01165^{* *} \\
(0.014)\end{array}$ & 0.58 & $\begin{array}{c}0.00945^{* * *} \\
(0.000)\end{array}$ & 0.51 \\
\hline$\rho$ & \multicolumn{2}{|c|}{$\begin{array}{c}0.82352^{* * * *} \\
(0.000)\end{array}$} & \multicolumn{2}{|c|}{$\begin{array}{c}0.82718^{* * *} \\
(0.000)\end{array}$} \\
\hline LR (zero slopes) & \multicolumn{2}{|c|}{$\begin{array}{c}6286.44 \\
(0.000)\end{array}$} & \multicolumn{2}{|c|}{$\begin{array}{l}5238.25 \\
(0.000)\end{array}$} \\
\hline Log likelihood & \multicolumn{2}{|c|}{-51920.8} & \multicolumn{2}{|c|}{-44813.9} \\
\hline Fraction of correct predictions (\%) & \multicolumn{2}{|c|}{69.19} & \multicolumn{2}{|c|}{68.78} \\
\hline Observations & \multicolumn{2}{|c|}{278.073} & \multicolumn{2}{|c|}{278.073} \\
\hline Number of firms & \multicolumn{2}{|c|}{30.897} & \multicolumn{2}{|c|}{30.897} \\
\hline
\end{tabular}

(a) marginal effects in percentage points calculated at sample means

* Statistically significant at $10 \%$ level

** Statistically significant at $5 \%$ level

*** Statistically significant at 1\% level 


\begin{tabular}{|c|c|c|c|c|}
\hline \multicolumn{5}{|c|}{$\begin{array}{l}\text { Table 11. Cash flow-investment correlations and financing constraints. Dependent variable: Capital expenditures }{ }_{\mathbf{t}} \\
\text { capital }_{\mathbf{t}-\mathbf{1}} \\
\text { p-values in parenthesis }\end{array}$} \\
\hline Quartile (financing constraint variable $=$ Trade credit(total liabilities) & Q1 & Q2 & Q3 & Q4 \\
\hline Cash flow $_{t} /$ capital $_{t-1}$ & $\begin{array}{c}0.3591 * * \\
(0.003) \\
\end{array}$ & $\begin{array}{c}0.5991 * * * \\
(0.000) \\
\end{array}$ & $\begin{array}{c}0.9781 * * * \\
(0.000) \\
\end{array}$ & $\begin{array}{c}0.9280 * * * \\
(0.000) \\
\end{array}$ \\
\hline Lagged dependent variable & $\begin{array}{l}0.0160 \\
(0.670) \\
\end{array}$ & $\begin{array}{c}-0.0730^{* *} \\
(0.011) \\
\end{array}$ & $\begin{array}{c}0.0733 * * \\
(0.031) \\
\end{array}$ & $\begin{array}{l}0.0587 \\
(0.412) \\
\end{array}$ \\
\hline Lagged dependent variable ${ }^{2}$ & $\begin{array}{l}0.0073 \\
(0.138) \\
\end{array}$ & $\begin{array}{c}0.0018^{* * *} \\
(0.002) \\
\end{array}$ & $\begin{array}{c}-0.10 \mathrm{E}-05 \\
(0.357) \\
\end{array}$ & $\begin{array}{c}0.17 \mathrm{E}-05^{* *} \\
(0.044)\end{array}$ \\
\hline Sales & $\begin{array}{c}0.92 \mathrm{E}-07 \\
(0.299) \\
\end{array}$ & $\begin{array}{c}0.11 \mathrm{E}-06 \\
(0.214)\end{array}$ & $\begin{array}{c}-0.39 \mathrm{E}-07^{* *} \\
(0.042)\end{array}$ & $\begin{array}{c}-0.24 \mathrm{E}-07 \\
(0.289)\end{array}$ \\
\hline$D e b t^{2}$ & $\begin{array}{c}-0.19 \mathrm{E}-07^{* *} \\
(0.022)\end{array}$ & $\begin{array}{c}-0.17 \mathrm{E}-07^{* *} \\
(0.023)\end{array}$ & $\begin{array}{c}-0.61 \mathrm{E}-07^{* *} \\
(0.020)\end{array}$ & $\begin{array}{c}-0.86 \mathrm{E} 07 * * \\
(0.032)\end{array}$ \\
\hline Adjusted $R^{2}$ & 0.97 & 0.96 & 0.99 & 0.99 \\
\hline Quartile (financing constraint variable $=$ Sales growth)) & Q1 & Q2 & Q3 & Q4 \\
\hline Cash $_{\text {flow }} /$ capital $_{t-1}$ & $\begin{array}{c}0.96446^{* * *} \\
(0.000) \\
\end{array}$ & $\begin{array}{c}0.95775^{* * *} * \\
(0.000) \\
\end{array}$ & $\begin{array}{c}0.48223 * * * \\
(0.000) \\
\end{array}$ & $\begin{array}{c}0.58530 * * * \\
(0.000) \\
\end{array}$ \\
\hline Lagged dependent variable & $\begin{array}{c}-0.02074 \\
(0.757) \\
\end{array}$ & $\begin{array}{c}-0.06562 \\
(0.755) \\
\end{array}$ & $\begin{array}{c}-0.01867 \\
(0.366) \\
\end{array}$ & $\begin{array}{c}0.02166 \\
(0.141) \\
\end{array}$ \\
\hline Lagged dependent variable ${ }^{2}$ & $\begin{array}{c}0.62 \mathrm{E}-06 \\
(0.171) \\
\end{array}$ & $\begin{array}{c}0.55 \mathrm{E}-06 \\
(0.212) \\
\end{array}$ & $\begin{array}{c}0.35 \mathrm{E}-06 \\
(0.320) \\
\end{array}$ & $\begin{array}{c}0.89 \mathrm{E}-06 * * * \\
(0.003)\end{array}$ \\
\hline Sales & $\begin{array}{c}0.72 \mathrm{E}-07 \\
(0.323) \\
\end{array}$ & $\begin{array}{c}0.35 \mathrm{E}-08 \\
(0.572) \\
\end{array}$ & $\begin{array}{c}-0.52 \mathrm{E}-08 \\
(0.446) \\
\end{array}$ & $\begin{array}{c}-0.40 \mathrm{E}-07 \\
(0.457) \\
\end{array}$ \\
\hline$D e b t^{2}$ & $\begin{array}{c}-0.18 \mathrm{E}-10 \\
(0.298) \\
\end{array}$ & $\begin{array}{c}0.15 \mathrm{E}-09 \\
(0.442) \\
\end{array}$ & $\begin{array}{c}-0.98 \mathrm{E}-10 \\
(0.716) \\
\end{array}$ & $\begin{array}{c}0.39 \mathrm{E}-10^{* * * *} \\
(0.008)\end{array}$ \\
\hline Adjusted $R^{2}$ & 0.99 & 0.99 & 0.99 & 0.99 \\
\hline Quartile (financing constraint variable $=$ Loans/tangible assets) & Q1 & Q2 & Q3 & Q4 \\
\hline Cash flow $_{t} /$ capital $_{t-1}$ & $\begin{array}{c}0.91499 * * * \\
(0.000)\end{array}$ & $\begin{array}{c}0.85164^{* * * *} \\
(0.000)\end{array}$ & $\begin{array}{c}0.55135^{* * * *} \\
(0.000)\end{array}$ & $\begin{array}{c}0.58231 * * * \\
(0.000)\end{array}$ \\
\hline Lagged dependent variable & $\begin{array}{c}-0.27680^{* * * *} \\
(0.008) \\
\end{array}$ & $\begin{array}{c}0.01129 \\
(0.350) \\
\end{array}$ & $\begin{array}{l}0.00163 \\
(0.558) \\
\end{array}$ & $\begin{array}{l}-0.0022 \\
(0.926) \\
\end{array}$ \\
\hline Lagged dependent variable ${ }^{2}$ & $\begin{array}{c}0.00012 * * * \\
(0.003)\end{array}$ & $\begin{array}{c}0.39 \mathrm{E}-06 \\
(0.138) \\
\end{array}$ & $\begin{array}{c}-0.67 \mathrm{E}-05 \\
(0.161) \\
\end{array}$ & $\begin{array}{c}0.16 \mathrm{E}-06 \\
(0.167) \\
\end{array}$ \\
\hline Sales & $\begin{array}{c}0.50 \mathrm{E}-07 \\
(0.793) \\
\end{array}$ & $\begin{array}{c}-0.31 \mathrm{E}-07 \\
(0.355) \\
\end{array}$ & $\begin{array}{c}0.52 \mathrm{E}-07^{*} \\
(0.079)\end{array}$ & $\begin{array}{c}-0.76 \mathrm{E}-08 \\
(0.698) \\
\end{array}$ \\
\hline$D e b t^{2}$ & $\begin{array}{c}-0.20 \mathrm{E}-10 \\
(0.654)\end{array}$ & $\begin{array}{c}0.26 \mathrm{E}-10^{* * * *} \\
(0.008)\end{array}$ & $\begin{array}{c}-0.39 \mathrm{E}-10 \\
(0.648) \\
\end{array}$ & $\begin{array}{c}-0.36 \mathrm{E}-10 \\
(0.724) \\
\end{array}$ \\
\hline Adjusted $R^{2}$ & 0.98 & 0.99 & 0.99 & 0.99 \\
\hline Quartile (financing constraint variable $=$ Trade credit/tangible assets) & Q1 & Q2 & Q3 & Q4 \\
\hline Cash flow $_{t} /$ capital $_{t-1}$ & $\begin{array}{c}0.32780 * * * \\
(0.000)\end{array}$ & $\begin{array}{c}0.457754 * * * \\
(0.000) \\
\end{array}$ & $\begin{array}{c}0.86695 * * * \\
(0.000)\end{array}$ & $\begin{array}{c}0.97559 * * * \\
(0.000)\end{array}$ \\
\hline Lagged dependent variable & $\begin{array}{l}0.02004 \\
(0.132) \\
\end{array}$ & $\begin{array}{c}0.04319 \\
(0.217) \\
\end{array}$ & $\begin{array}{c}-0.18542 \\
(0.204) \\
\end{array}$ & $\begin{array}{c}0.0483^{* *} \\
(0.014) \\
\end{array}$ \\
\hline Lagged dependent variable ${ }^{2}$ & $\begin{array}{c}0.62 \mathrm{E}-05^{* * * *} \\
(0.000)\end{array}$ & $\begin{array}{c}0.38 \mathrm{E}-06 \\
(0.103) \\
\end{array}$ & $\begin{array}{c}0.29 \mathrm{E}-05 \\
(0.114) \\
\end{array}$ & $\begin{array}{c}0.69 \mathrm{E}-06^{* * * *} \\
(0.000)\end{array}$ \\
\hline Sales & $\begin{array}{c}0.12 \mathrm{E}-07 \\
(0.838) \\
\end{array}$ & $\begin{array}{c}0.21 \mathrm{E}-07 \\
(0.414) \\
\end{array}$ & $\begin{array}{c}0.13 \mathrm{E}-06 \\
(0.530) \\
\end{array}$ & $\begin{array}{c}0.21 \mathrm{E}-08 \\
(0.822) \\
\end{array}$ \\
\hline$D e b t^{2}$ & $\begin{array}{c}0.22 \mathrm{E}-10 \\
(0.837) \\
\end{array}$ & $\begin{array}{c}0.65 \mathrm{E}-10 \\
(0.602) \\
\end{array}$ & $\begin{array}{c}0.32 \mathrm{E}-09 \\
(0.334) \\
\end{array}$ & $\begin{array}{c}0.31 \mathrm{E}-09 \\
(0.859) \\
\end{array}$ \\
\hline Adjusted $R^{2}$ & 0.99 & 0.99 & 0.97 & 0.99 \\
\hline Quartile (financing constraint variable $=$ Disequilibrium model) & Q1 & Q2 & Q3 & Q4 \\
\hline Cash flow $_{t} /$ capital $_{t-1}$ & $\begin{array}{c}0.37852 * * * \\
(0.000)\end{array}$ & $\begin{array}{c}0.52354 * * * \\
(0.000) \\
\end{array}$ & $\begin{array}{c}0.97524 * * * \\
(0.000) \\
\end{array}$ & $\begin{array}{c}0.92927 * * * \\
(0.000) \\
\end{array}$ \\
\hline Lagged dependent variable & $\begin{array}{c}0.12367 \\
(0.104) \\
\end{array}$ & $\begin{array}{c}0.10587 \\
(0.304) \\
\end{array}$ & $\begin{array}{c}0.13509^{*} \\
(0.098)\end{array}$ & $\begin{array}{c}0.12063 \\
(0.149) \\
\end{array}$ \\
\hline Lagged dependent variable ${ }^{2}$ & $\begin{array}{c}0.73 \mathrm{E}-06^{* * * *} \\
(0.003)\end{array}$ & $\begin{array}{c}0.62 \mathrm{E}-06^{* *} \\
(0.012)\end{array}$ & $\begin{array}{c}0.68 \mathrm{E}-06^{* * * *} \\
(0.008)\end{array}$ & $\begin{array}{c}0.25 \mathrm{E}-07^{* *} \\
(0.016) \\
\end{array}$ \\
\hline Sales & $\begin{array}{c}0.13 \mathrm{E}-07 \\
(0.658) \\
\end{array}$ & $\begin{array}{c}0.25 \mathrm{E}-07 \\
(0.509) \\
\end{array}$ & $\begin{array}{c}0.34 \mathrm{E}-07 \\
(0.602)\end{array}$ & $\begin{array}{c}0.22 \mathrm{E}-07 \\
(0.502)\end{array}$ \\
\hline$D e b t^{2}$ & $\begin{array}{c}0.59 \mathrm{E}-10 \\
(0.904)\end{array}$ & $\begin{array}{c}0.60 \mathrm{E}-10 \\
(0.806) \\
\end{array}$ & $\begin{array}{c}0.47 \mathrm{E}-09 \\
(0.763) \\
\end{array}$ & $\begin{array}{c}0.28 \mathrm{E}-09 \\
(0.397) \\
\end{array}$ \\
\hline Adjusted $R^{2}$ & 0.99 & 0.99 & 0.99 & 0.99 \\
\hline Observations & 69.525 & 69.516 & 69.516 & 69.516 \\
\hline Number of firms & 7.725 & 7.724 & 7.724 & 7.724 \\
\hline $\begin{array}{l}* \text { Statistically significant at } 10 \% \text { level } \\
* * \text { Statistically significant at } 5 \% \text { level } \\
* * * \text { Statistically significant at } 1 \% \text { level }\end{array}$ & & & & \\
\hline
\end{tabular}

